University of Nebraska - Lincoln

DigitalCommons@University of Nebraska - Lincoln

Agronomy \& Horticulture -- Faculty Publications

Agronomy and Horticulture Department

$1-1942$

\title{
History of the Native Vegetation of Western Kansas During Seven Years of Continuous Drought
}

\author{
F. W. Albertson \\ Fort Hays Kansas State College \\ J. E. Weaver \\ University of Nebraska-Lincoln
}

Follow this and additional works at: https://digitalcommons.unl.edu/agronomyfacpub

Part of the Plant Sciences Commons

Albertson, F. W. and Weaver, J. E., "History of the Native Vegetation of Western Kansas During Seven Years of Continuous Drought" (1942). Agronomy \& Horticulture -- Faculty Publications. 479. https://digitalcommons.unl.edu/agronomyfacpub/479

This Article is brought to you for free and open access by the Agronomy and Horticulture Department at DigitalCommons@University of Nebraska - Lincoln. It has been accepted for inclusion in Agronomy \& Horticulture -Faculty Publications by an authorized administrator of DigitalCommons@University of Nebraska - Lincoln. 
Ecological Monographs, Vol. 12, No. 1 (Jan., 1942), pp. 23-51

Copyright 1942 Ecological Society of America. Used by permission.

HISTORY OF THE NATIVE VEGETATION OF WESTERN

KANSAS DURING SEVEN YEARS OF

CONTINUOUS DROUGHT

F. W. Albertson

Fort Hays Kansas State Ciollege

AND

J. E. WEAvER

University of Nebraska 
TABLE OF CONTENTS

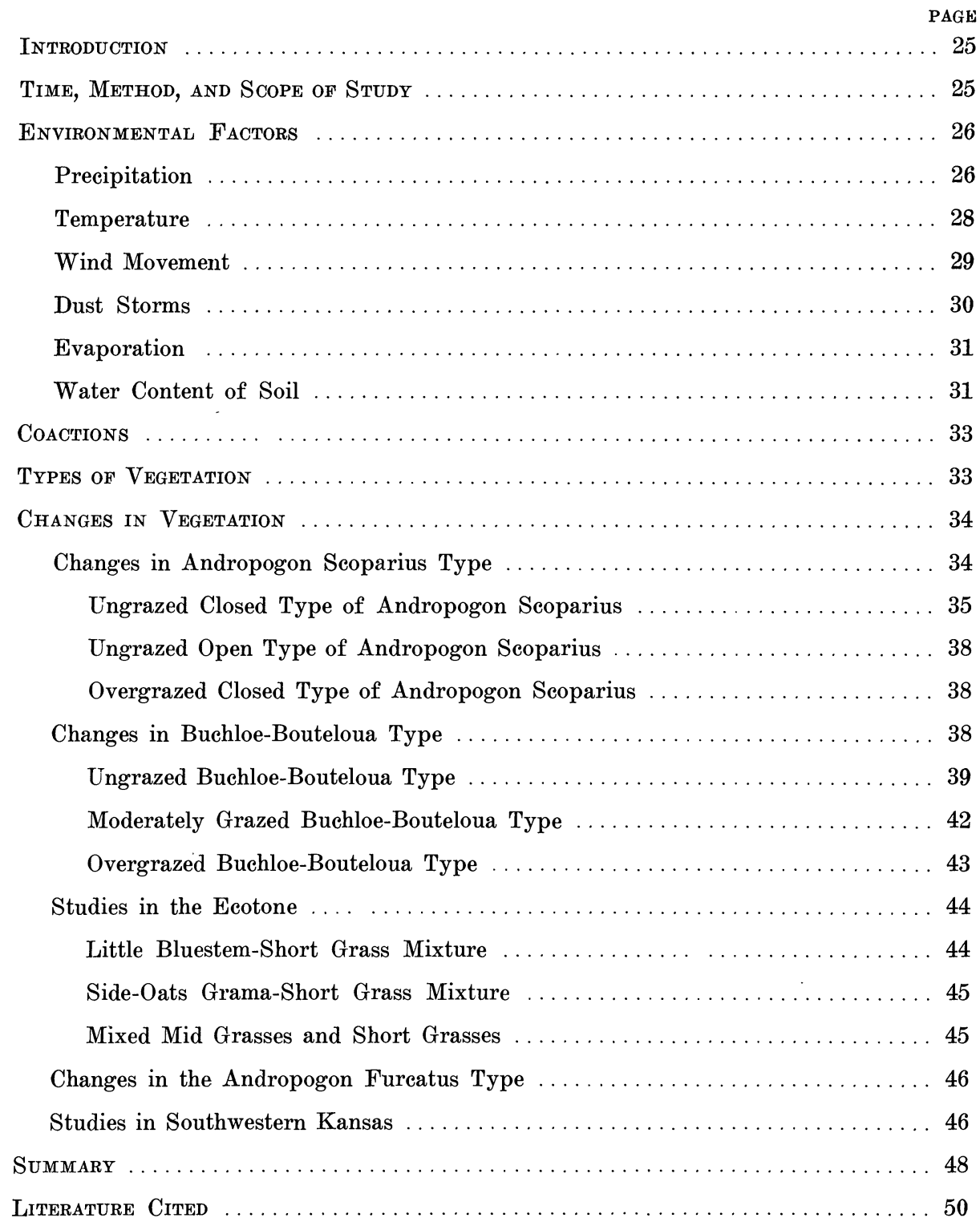




\section{HISTORY OF THE NATIVE VEGETATION OF WESTERN KANSAS DURING SEVEN YEARS OF CONTINUOUS DROUGHT*}

\section{INTRODUCTION}

When the pioneers came from the East to make new homes in the Great Plains region, they found a dense cover of native vegetation. It was disturbed only by buffaloes, prairie dogs, other plains animals, Indians, and prairie fires. The Federal Government required that a certain amount of land be broken and put under cultivation, whether the land was obtained as a homestead or as a timber claim (McArdle and Costello, 1936).

The practice of the settlers was to break up a small tract of the prairie on which they could grow enough winter feed to sustain their cattle, horses, and other animals. The remainder was kept for pasture. Frequently the cultivated fields were cropped for a number of years and then abandoned to return to native prairie. Then the pioneers broke up and put under cultivation other similar areas (Clements and Chaney, 1937).

As the number of settlers increased and the demand for small grains, corn and sorghum became greater, additional acres were put under the plow. Agriculture approached stability with the growing of grain and forage crops incidental to the production of livestock. With the introduction of labor-saving machinery, it became possible for more land to be cultivated with even less manpower. This stimulated more extensive crop production. Even with the increased demands for farm products, the native grassland still remained of great importance to the farmer who kept livestock to increase his income.

The native grasslands of the Great Plains region are exceedingly important to the economic well-being of the people of the midwest. It is estimated that at present there are approximately $100,000,000$ acres of land under cultivation, as compared with $175,000,000$ that remain unbroken (Great Plains Committee, 1936).

The high prices of wheat during and following the World War caused many farmers, as well as wheat-farming corporations, to break vast areas in western Kansas. In fact, immense areas that had previously been regarded as "too risky" for growing wheat were broken for erop production. It is estimated that $18,000,000$ acres are now under cultivation. In comparison, only $11,000,000$ acres of grassland remain. Until about 1930, there was an unlimited market for wheat. Many farmers amassed considerable wealth through an extensive use of this one-crop system (Shantz, 1911).

At the beginning of the past decade, however, the wheat market reached the saturation point, and the

* This study was made with the aid of a grant from the Penrose Fund of the American Philosophical Society. price was reduced to less than 30 cents per bushel. Even at this low price it was impossible to dispose of any great quantity. Another factor that changed the outlook of the farmers was the period of deficient rainfall that appeared early in the "thirties." As a consequence of this drought, it was impossible to produce adequate erops; hence, the increased need for more grassland. But since the amount of the range land could not be increased in proportion to the demand, overgrazing resulted. This, in turn, led to a breakdown of the prairies. As cultivation continued despite the decreased rainfall, the soil became more pulverized, less porous, and more susceptible to erosion both by wind and water. Runoff was increased many fold, and the rate of erosion was accelerated enormously. One dashing shower sometimes removed as much as an inch of fertile soil, an amount which is produced naturally over a period of several hundred years (McDonald, 1938; Bennett, 1939). Dust storms which have occurred on the Great Plains since 1934 have been of unprecedented extent and intensity (Brandon and Kezer, 1936).

Just when the raising of cultivated crops became less important and the need for good pastures much more so, the combined effects of drought, dust, and overgrazing reduced the yield of vast areas of grasslands in the Great Plains region to almost nil.

\section{TIME, METHOD, AND SCOPE OF STUDY}

Studies of environmental factors and the reactions of vegetation were begun at Hays, Kansas, in 1931, before the drought. They have been continued almost uninterruptedly to the present time. Available soil moisture, measured throughout each growing season, has been found to be the most important factor of the environment of the plant. Precipitation, temperature, wind movement, and evaporation, also regularly measured, influence vegetation primarily through their effect upon the water supply or its loss. Permanent meter quadrats were extensively employed in obtaining quantitative data pertaining to plant reactions. In charting them, the pantograph was used, and the planimeter was employed in measuring the areas occupied by various species. ${ }^{1} \mathrm{Nu}$ merous quadrats were staked out in 1932 and others subsequently, and each has been charted annually. Other methods of study were used, such as list quadrats, belt transects, and bisects. Field notes were extensively taken over wide areas. The area studied extends from Phillipsburg, near the northern edge of Kansas, through Hays, and to the southwest as

1 Areas too small to be measured accurately by the planimeter were determined by superimposing circles of known area, in those of the charted quadrat sheet. 


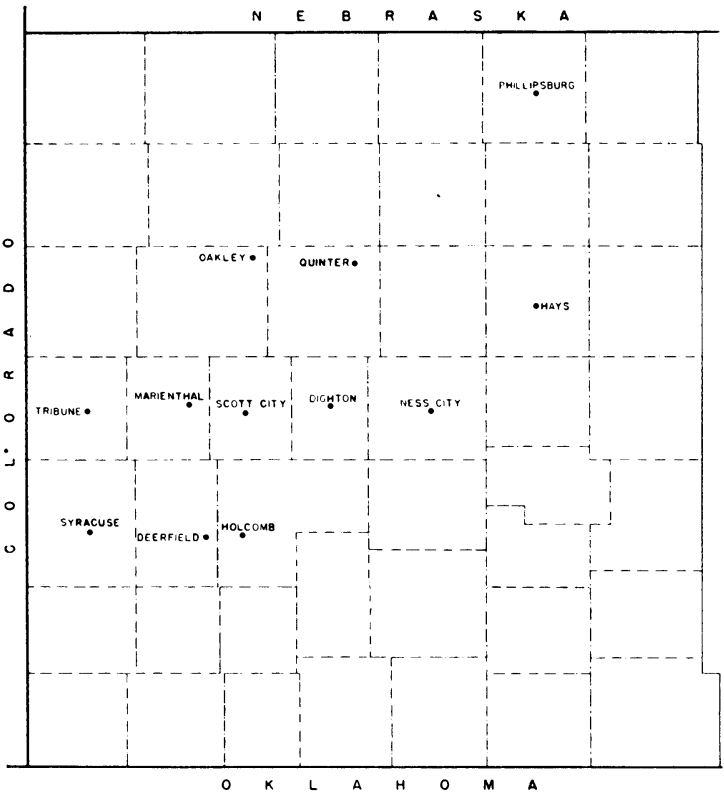

Fig. 1. Map showing the stations in Kansas where studies were made. These investigations have been continued since 1923 at Phillipsburg. They were initiated at Hays in 1931, and at the other stations in 1937.

far as Syracuse (Fig. 1). This work is a continuation of earlier studies by the authors (Weaver, 1924; Weaver and Albertson, 1936, 1939) and is supplemented by two related studies made in 1940 (Weaver and Albertson, 1940, 1940a).

\section{ENVIRONMENTAL FACTORS}

The average annual precipitation at Hays, Kansas, was approximately 5 inches above the normal (22.9 inches) during the 6 years (1927-1932) preceding the drought. Other environmental factors were likewise more conducive than usual to the growth of native prairie plants. Prairies moderately grazed were in excellent condition, but those that were ungrazed accumulated so much debris that the basal cover afforded by living plants was greatly reduced. The more mesic vegetation advanced up the slopes from the moist ravines and lowlands to the more xeric hillsides and tablelands. Big bluestem (Andropogon furcatus), for example, which normally grows in ravines, was found in considerable quantities in the depressions or "buffalo wallows" on the nearly level uplands in 1932, at the end of the wet period. Little bluestem (Andropogon scoparius) and the wire grasses (Aristida purpurea and A. longiseta) likewise spread from their strongholds on the hillsides into the short-grass areas of the level uplands. It was not uncommon to find scattered bunches of these throughout the short-grass type. In general, plant production was somewhat above normal, and this luxuriance of growth made the vegetation more susceptible to the drought that followed (Clements, 1929).
The low rainfall during the dry years was accompanied by low relative humidity, high temperature, high wind velocity, and extremely high rates of evaporation. The damaging effect of insufficient precipitation was intensified by the fact that during the warm season, when soil moisture was most essential to growth, precipitation was often much less than normal.

\section{Precipitation}

The annual precipitation for the drought period during which this study was made (1933-1939) was below normal for every year (Fig. 2). ${ }^{2}$ Only 3 of

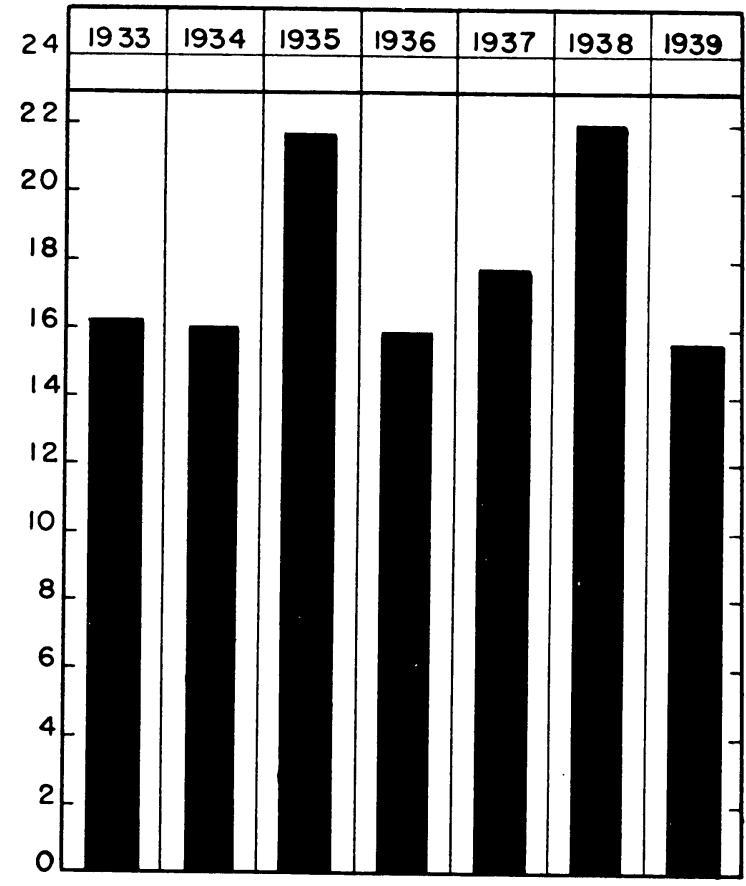

Fig. 2. Total precipitation in inches at Hays, Kansas, for 1933 to 1939 , inclusive, and mean annual precipitation (heavy horizontal line).

the 7 years even closely approached normal, and during one of these 3 (1937) there was over 5 inches deficit. The remaining 4 years $(1933,1934,1936$, and 1939) each had approximately 16 inches, which is nearly 7 inches below normal.

Precipitation of the growing season (April to September) has a greater effect in determining the survival or death of the vegetation than has total precipitation for the year. May was the only month in which precipitation averaged above normal for the entire period and this resulted from several unusually heavy rains during May of 1935, 1936, and 1938 (Fig. 3). During 3 of the 7 years, rainfall for May was far below normal. The value accrued from the surplus moisture was offset by extremely abnormal conditions before and following the rainy period. In 1935, for example, 7 weeks of plentiful rainfall

2 Data on precipitation and temperature were secured from the U.S. Weather Bureau. 


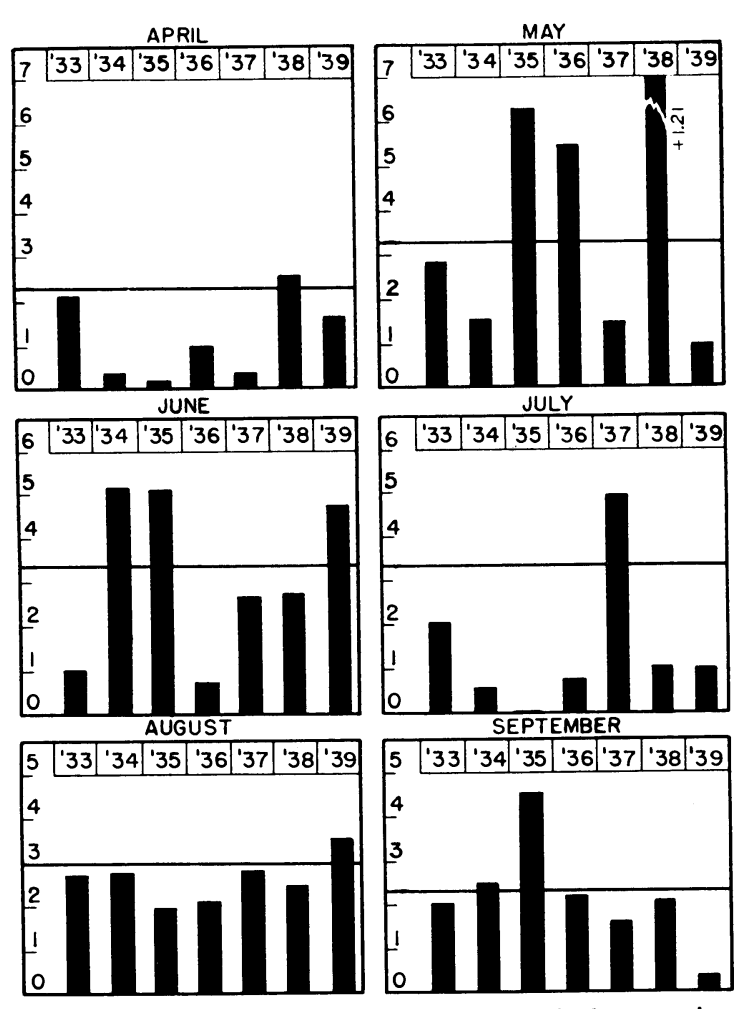

Fig. 3. Rainfall during each month of the growing season at Hays, Kansas, from 1933 to 1939, inclusive, and mean monthly rainfall (heavy horizontal lines).

during May and early June were preceded by the worst dust storms on record. The wet period was followed by one of equal length with scarcely any precipitation. It was during the month of July, 1935, that only 0.01 inch of rain fell. Rainfall for July, when soil moisture is indispensable to plant growth, averaged only 45 percent normal during the 7-year period. Only 2 years (1935 and 1938) had precipitation of about an inch or less below normal. Much of that in 1935 was lost because of the relatively impervious mantle of dust that was deposited over most of the soil and vegetation in March and April.

The total annual precipitation for the years 1933 to 1939 , inclusive, was 34.46 inches below normal (Table 1). The amount received over a period of 7 years was approximately equal to what would be expected in $5 \frac{1}{2}$ years of normal precipitation. Furthermore, it was over 40 inches less than that received the 6 years previous to the beginning of the drought in 1933.

The accumulated deficit for the first 2 years of the drought (1933 and 1934) amounted to 13.5 inches. That during 1935 added only another inch, but this was followed by 2 years when the deficit was further augmented by over 12 inches, increasing the total to 26.6 inches. The precipitation for 1938 was only 0.8 inch below normal, but this resulted from an excess of nearly 5 inches in May. The deficiency for
TABLE 1. Mean monthly precipitation with departure from normal (1868-1939) and total departure each month (in inches), percent of normal precipitation for all years of each month, and accumulated deficits 1933 to 1939 at Hays, Kansas.

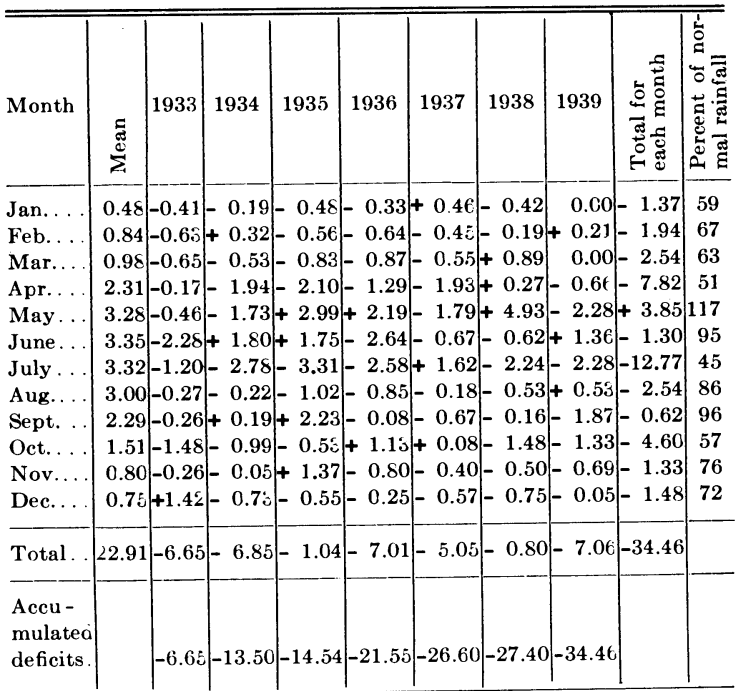

the extremely dry year of 1939 was over 7 inches. This increased the total for the 7 years to 34.46 inches.

Rainfall data were also compiled for the years 1937, 1938, and 1939 from measurements made at the several stations in western Kansas where quantitative studies were conducted (Fig. 4). At all sta-

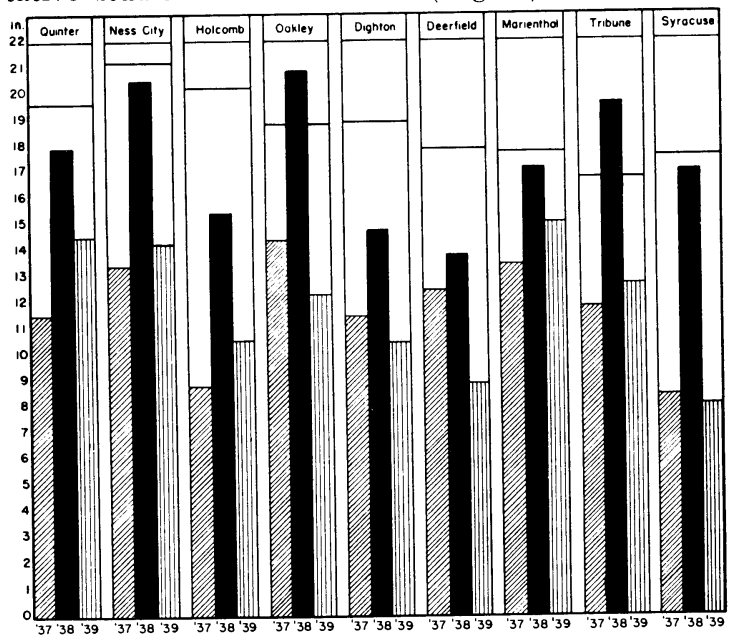

Fig. 4. Mean annual precipitation (horizontal lines) and annual precipitation during 1937, 1938, and 1939, at nine stations in western Kansas.

tions, the precipitation in 1938 was the greatest of the 3 years. In four places, the rainfall for 1937 exceeded that of 1939 ; in five, the reverse condition prevailed. The normal precipitation, deviation from the normal, the total deficit, and the percent of normal precipitation for these 3 years are given in Table 2. The mean precipitation at Ness City (21.24 
TABLE 2. Mean annual precipitation (in inches), deviation from the mean, total deficit, and percent of normal during 1937 to 1939 , inclusive, at nine western Kansas stations.

\begin{tabular}{|c|c|c|c|c|c|c|}
\hline \multirow{2}{*}{ Station } & \multirow{2}{*}{$\begin{array}{l}\text { Normal } \\
\text { precip- } \\
\text { itation }\end{array}$} & \multicolumn{3}{|c|}{ Deviation from normal } & \multirow{2}{*}{$\begin{array}{c}\text { Tota] } \\
\text { deficit }\end{array}$} & \multirow{2}{*}{$\begin{array}{c}\text { Percent of } \\
\text { normal } \\
\text { rain.a.l } \\
3 \text { years }\end{array}$} \\
\hline & & 1937 & 1938 & 1939 & & \\
\hline Quinter. & 19.56 & -8.08 & -1.57 & -5.02 & -14.67 & 75.0 \\
\hline Ness City.. & 21.24 & -7.86 & -0.88 & -6.97 & -15.71 & 75.3 \\
\hline Holcomb . & 20.22 & -11.35 & -4.78 & -9.77 & -25.90 & 57.3 \\
\hline Oakley . & 18.83 & -4.49 & +2.10 & -6.57 & -8.96 & 84.1 \\
\hline Dighton. & 18.87 & -7.37 & -4.11 & -8.30 & -19.78 & 65.0 \\
\hline Deerfield. & 17.89 & -5.20 & -4.15 & -9.06 & -18.41 & 65.7 \\
\hline Marienthal. & 17.75 & -4.08 & -0.64 & -2.69 & -7.41 & 86.0 \\
\hline Tribune... & 16.72 & -4.87 & +2.93 & -4.05 & -5.99 & 88.1 \\
\hline Syracuse.. & 17.67 & -9.25 & -0.65 & -9.60 & -19.50 & 63.2 \\
\hline
\end{tabular}

inches) was the greatest at any of the stations where studies were made. It was least at Tribune with 16.72 inches. The precipitation was below normal in every location for each year except 1938, when it was 2.1 and 2.93 inches above the mean at Oakley and Tribune, respectively. The accumulated deficit for the 3 years ranged from 5.99 inches at Tribune to 25.9 at Holcomb. At four of the nine stations, the total for 3 years was actually less than that which would normally be expected in 2 years. The percentage of total normal precipitation for the 3-year period ranged from 57.3 at Holcomb to 88.1 at Tribune.

The deviation from the mean annual precipitation for the entire state, the middle division, the western division, and for Hays is given in Table 3. These

TABLE 3. Deviation (in inches) from the mean annual precipitation in Kansas, 1927 to 1939, inclusive.

\begin{tabular}{|c|c|c|c|c|c|c|c|}
\hline Location & 1927 & 1928 & 1929 & 1930 & 1931 & 1932 & 1933 \\
\hline Entire State. & +5.63 & +6.57 & +1.18 & 0.00 & -1.24 & -3.54 & -4.74 \\
\hline Middle Division & +5.44 & +6.45 & +2.15 & -0.33 & -1.79 & -3.17 & -6.97 \\
\hline Western Division. & -0.51 & +7.99 & -0.13 & +3.86 & -3.62 & -2.39 & -1.36 \\
\hline Hays........ & +4.41 & +7.14 & +3.77 & +2.23 & +3.15 & +8.75 & -6.65 \\
\hline \multicolumn{2}{|l|}{ Location } & 1934 & 1935 & 1936 & 1937 & 1938 & 1939 \\
\hline \multirow{4}{*}{\multicolumn{2}{|c|}{$\begin{array}{l}\text { Entire State ......... } \\
\text { Middle Division ....... } \\
\text { Western Division .... } \\
\text { Hays ............. }\end{array}$}} & -6.77 & +1.64 & -8.34 & -5.66 & +0.71 & -6.35 \\
\hline & & -5.76 & +1.41 & -8.52 & -4.07 & +2.08 & -5.04 \\
\hline & & -8.00 & -3.77 & -5.21 & -6.15 & -0.89 & -5.91 \\
\hline & & -6.85 & -1.04 & -7.01 & -5.05 & -0.80 & -7.06 \\
\hline
\end{tabular}

data indicate that deficient precipitation did not occur simultaneously over the entire state. For example, the drought did not begin at Hays until 1933, but in the middle division it made its appearance in 1930 and in the western division in 1931.

\section{TEMPERATURE}

The average monthly and mean annual temperatures for the 8-year period immediately preceding the drought (1925 to 1932 ), those for the 3 best years of the drought $(1935,1937,1938)$, and those for the 4 worst years of the drought are shown in Table 4 . The average of the years 1925 to 1932 was fairly typical, the mean annual temperature being only $.7^{\circ} \mathrm{F}$. above normal.
TABLE 4. Average monthly and mean annual tem. peratures with annual departures from the normal: (A) $1925-1932$, (B) for the 3 best years of the drought and (C) for the 4 worst years of the drought at Hays, Kansas.

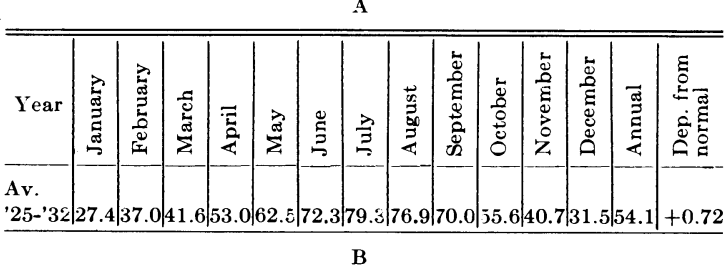

$1935|34.2| 38.2|50.4| 52.0|58.4| 70.0|83.6| 81.0|69.4| 54.2|39.4| 33.9|55.4|+2.0$

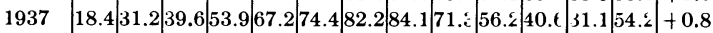

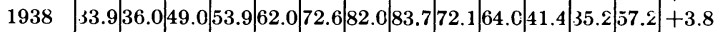
\begin{tabular}{l|l|l|l|l|l|l|l|l|l|l|l|l|l|l|}
\hline Av. & 28.8 & 35.1 & 46.3 & 53.2 & $62 . \varepsilon$ & 72.2 & 82.6 & 32.9 & 70.6 & 58.1 & 40.4 & 3.4 & 55.5 & +2.1 \\
\hline
\end{tabular}

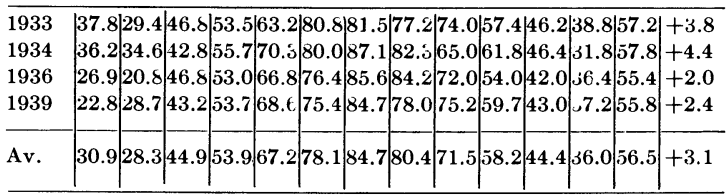

During the 3 years 1935, 1937, and 1938, the mean annual temperature was $2.1^{\circ}$ above normal, and in 1938, the year of greatest rainfall, it was $3.8^{\circ}$ above normal. The average for the 4 worst years of the drought $(1933,1934,1936,1939)$ was $3.1^{\circ}$ above normal. The greatest departure from normal was in 1934 when the mean annual temperature averaged $4.4^{\circ}$ above.

The monthly average of maximum daily temperatures for the growing season (April to September) has a profound effect upon the vegetation. At no time during the growing seasons of 1925 to 1932, inclusive, did the average daily maximum for the month reach $100^{\circ} \mathrm{F}$. (Table 5). The average for July during this 8-year period was $93.1^{\circ}$. It varied from $96.7^{\circ}$ in July, 1930 , to $88.7^{\circ}$ in 1928. The average maximum daily temperatures for June and August were $7.9^{\circ}$ and $2.7^{\circ}$, respectively, below that of July. These temperatures are in direct contrast with those of the drought years when the temperature was not only much higher but high temperatures also of much greater duration. For example, the average daily maximum for July, 1935, 1937, and 1938 , was $4.7^{\circ}$ above the fairly normal period of 1925 to 1932 . In making the same comparison for August, a difference of $7.5^{\circ}$ was found. The temperature during the 4 driest years of the drought was even higher and of greater duration. The average maximums for June, July, and August were $93.2^{\circ}$, $100.6^{\circ}$, and $94.8^{\circ}$, respectively, or $8.0^{\circ}, 7.5^{\circ}$, and $4.4^{\circ}$ higher than the fairly normal period of 1925 to 1932 .

The average maximum temperatures for the three periods (predrought period, 3 best years of drought, and 4 worst years of drought) were nearly the same in April and again in September. This is likewise true for the mean daily temperatures (Fig. 5). In 
TABLE 5. Monthly average of maximum daily temperatures at Hays, Kansas: (A) for 6 summer months of 1925 to 1932 , (B) for $1935,1937,1938$, and (C) for 1933, 1934, 1936, 1939.

\begin{tabular}{|c|c|c|c|c|c|c|}
\hline Year & April & May & June & July & August & Sept. \\
\hline $1925 \ldots$ & 70.9 & 75.5 & 92.6 & 93.1 & 89.2 & 85.3 \\
\hline $1926 \ldots \ldots$ & 62.7 & 78.6 & 88.5 & 94.5 & 95.9 & 81.3 \\
\hline $1927 \ldots \ldots$ & 68.5 & 78.1 & 82.0 & 90.1 & 82.2 & 82.1 \\
\hline 1928. & 65.2 & 76.9 & 75.6 & 88.7 & 89.0 & 83.7 \\
\hline 1929. & 69.6 & 71.8 & 83.9 & 91.7 & 91.7 & 80.1 \\
\hline $1930 \ldots$ & 72.3 & 74.5 & 84.0 & 96.7 & 93.5 & 84.3 \\
\hline $1931 \ldots \ldots$ & 64.8 & 71.5 & 91.0 & 93.7 & 90.1 & 93.7 \\
\hline 1932. & 70.7 & 79.4 & 84.1 & 96.4 & 91.7 & 80.7 \\
\hline Average & 68.0 & 75.9 & 85.2 & 93.1 & 90.4 & 83.9 \\
\hline
\end{tabular}

B

\begin{tabular}{l|c|c|c|c|c|c}
\hline $1935 \ldots \ldots$ & 65.3 & 68.1 & 81.2 & 99.1 & 95.8 & 83.8 \\
$1937 \ldots \ldots$ & 70.0 & 81.3 & 87.9 & 96.9 & 99.0 & 85.5 \\
$1938 \ldots \ldots$ & 66.1 & 73.8 & 85.2 & 97.6 & 99.0 & 87.2 \\
\hline Average ... & 67.1 & 74.4 & 84.7 & 97.8 & 97.9 & 85.5 \\
\hline
\end{tabular}

\begin{tabular}{|c|c|c|c|c|c|c|}
\hline $1933 \ldots \ldots$ & 66.3 & 77.3 & 97.2 & 96.3 & 90.4 & 89.0 \\
\hline $1934 \ldots$ & 71.6 & 85.5 & 94.7 & 103.6 & 97.1 & 78.8 \\
\hline $1936 \ldots$ & 69.6 & 77.8 & 91.6 & 101.4 & 100.3 & 84.0 \\
\hline $1939 \ldots \ldots$ & 67.6 & 84.2 & 89.3 & 101.1 & 91.7 & 91.5 \\
\hline Average & 68.7 & 81.2 & 93.2 & 100.6 & 94.8 & 85.8 \\
\hline
\end{tabular}

general, differences increased from April, reached a maximum in July, and gradually decreased until they were negligible by the end of August.

Wind Movement

Total miles of wind movement for each month of the growing season for the drought years are given in Table $6 .^{3}$ April had the greatest average wind

TABLE 6. Total miles of wind movement per month at Hays, Kansas, during the growing seasons of 1933 to 1939, inclusive. Also, the average for the 32-year period (1908 to 1939) and the drought period (1933 to 1939).

\begin{tabular}{c|c|c|c|c|c|c|c}
\hline \hline Year & April & May & June & July & Aug. & Sept. & $\begin{array}{c}\text { Total for } \\
\text { growing } \\
\text { season }\end{array}$ \\
\hline $1933 \ldots \ldots \ldots$ & 6,931 & 6,360 & 5,976 & 5,040 & 4,920 & 5,592 & 34,819 \\
$1934 \ldots \ldots \ldots$ & 6,550 & 7,488 & 7,056 & 7,416 & 6,192 & 7,080 & 41,782 \\
$1935 \ldots \ldots \ldots$ & 9,657 & 7,608 & 5,832 & 6,048 & 6,120 & 5,880 & 41,145 \\
$1936 \ldots \ldots \ldots$ & 6,876 & 5,712 & 4,824 & 5,760 & 4,440 & 6,216 & 33,828 \\
$1937 \ldots \ldots \ldots$ & 7,809 & 6,912 & 6,212 & 5,424 & 8,256 & 5,328 & 39,941 \\
$1938 \ldots \ldots \ldots$ & 8,505 & 5,664 & 4,944 & 5,016 & 6,648 & 4,680 & 35,457 \\
$1939 \ldots \ldots \ldots$ & 7,528 & 7,104 & 7,080 & 6,268 & 5,760 & 6,960 & 40,700 \\
\hline Average.... & 7,693 & 6,692 & 5,989 & 5,853 & 6,048 & 5,961 & 38,239 \\
\hline 1908 to 1939 & 7,452 & 6,540 & 5,746 & 5,237 & 5,218 & 5,978 & 36,171 \\
\hline
\end{tabular}

velocity for the drought period. The total number of miles of wind movement per month for the growing season was highest for April during 5 of the 7 years. The average for the 7-year period $(7,693$ miles) was approximately 1,000 miles greater than for May and over 1,600 miles greater than for $\mathrm{Au}$ -

3 Data on wind movement and evaporation were obtained from measurements made at Hays, Kansas, by the Division of partment of Agriculture.

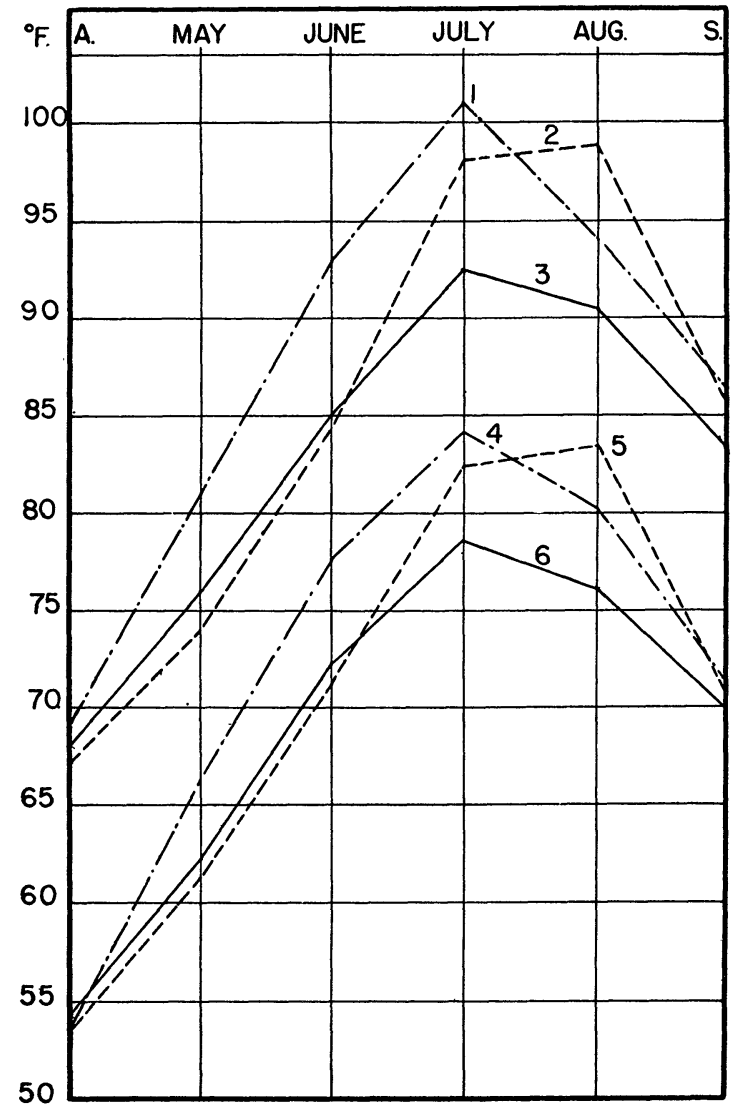

Frg. 5. Graphs showing average daily maximum temperature: 1 , of 4 worst drought years (1933, 1934, 1936 , and 1939); 2 , of 3 best drought years (1935, 1937, and 1938); and 3 , of predrought period (1925 to 1932). Mean daily temperatures: 4 , of 4 worst drought years; 5 , of 3 best drought years; and 6 , of predrought period.

gust. In 1935, April had a total wind movement of 9,657 miles, which was over 1,100 miles greater than April, 1938, and nearly 2,000 miles greater than the monthly average for the drought period.

The average total wind movement per month for the drought period was greater than the normal (1908 to 1939) for every month of the growing season except September, which was only slightly below normal. The total wind movement for the growing season of 1934 was highest, being 41,782 miles. That of 1935 and 1939 was only slightly less-41,145 and 40,700 miles, respectively. Wind movement for the growing season of 1935 totaled high because of the very strong winds of April and early May. The remaining 2 years of most severe drought (1933 and 1936) had less wind movement-34,819 and 33,828 miles, respectively. There were three seasons (1933, 1936, and 1938) for which the total wind movement for the season was below normal. During the remaining four seasons wind movement ranged from 3,770 miles (in 1937) to 5,611 miles (in 1934) above normal. 


\section{DUst Storms}

The combined effects of cultivation, overgrazing, and drought ereated a condition in the surface soil which was extremely conducive to the blowing of dust by the wind. Deficient rainfall in the middle and western portion of the state of Kansas began in 1931 (Table 3). As the soil became drier and more barren, cultivation was more effective in pulverizing the surface soil to the extent that it could be easily lifted by the wind. Dust storms in western Kansas were frequent but not severe during 1932. In 1933 there were many local dust storms and several were of wide extent and especially severe on April 13, 19, and 29. Lights were necessary in the middle of the afternoon, and such darkness prevailed that chickens went to roost soon after midday.

The season of 1934 was not considered a dusty one, even though it was extremely dry. Dust storms were more frequent and widespread in April, however, than they had been in any other month in the history of the state.

The blowing of dust reached a climax in March and April of 1935. The extremely high wind velocity during these two months was all that was necessary to initiate the black blizzards in the vast areas covered with dry, pulverized soil. Even as early as February 21 and 24, dust storms were unusually severe. They occurred on approximately half of the days after March 15; in fact, on some occasions, the air was filled with dust for a period of several days at a time. Often a dust storm approaching from a distance had much the appearance of an extremely dark rain cloud, being driven by a wind of high velocity (Fig. 6).

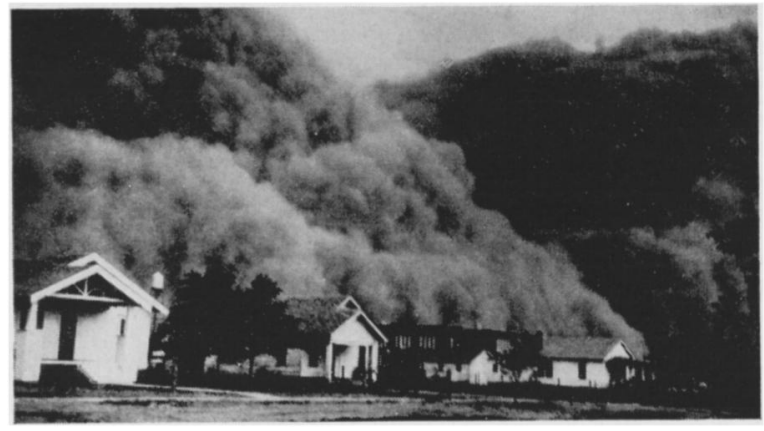

Photo by Conard

Fig. 6. Dust storms at Hugoton in southwestern Kansas, typical of the black blizzards of the great drought.

Visibility in the areas covered by these "dusters" was often reduced to only a few feet or even to zero. It was then necessary to follow the pavement curb and count the streets to find one's way home. Dust penetrated every crevice in the houses. As much as a quarter of an inch of dust accumulated over the floors and furniture. The dust storm of late afternoon and night of March 15 and 16 was reported to have been the most severe and most damaging ever known in northwestern and north-central Kansas.
Traffic on the highways was abandoned; trains were delayed; and, on many occasions, people were obliged to cover their faces with dampened handkerchiefs in order to breathe.

Much of the dust that was moved about was not actually suspended in the air but carried along the surface of the soil. The few growing plants that remained were often cut away as if they had been subjected to the action of a sand blast. In sections of the dust bowl, fence posts were not infrequently worn away so that only a small portion in the center remained. Enormous, tortuous drifts of soil, often as high as 30 inches, were deposited over the prairies, especially where vegetation such as yucca, sagebrush, or cactus caused the accumulation of soil. Vast areas of vegetation were smothered by the drifts of loose soil (Fig. 7).

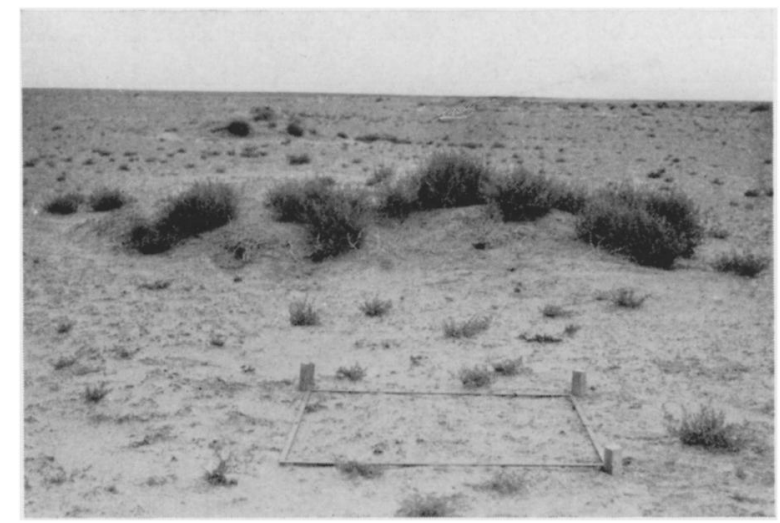

Fig. 7. Large drifts of dust, frequently 30 inches in height, were distributed over many of the grasslands of western Kansas. These drifts were later partially covered by Russian thistles and other weeds. Sometimes, as on this range, they were inhabited by pack rats.

Usually much of the fine silt was suspended in the air and often carried great distances and deposited where no actual blowing of the soil had occurred. ${ }^{4}$ Extensive grasslands that lay far from cultivated fields were commonly covered by a layer of this fine silt to a depth of $1 / 2$ inch to over 1 inch. "Dusting" of this nature was continued late into April, 1935, and, according to records, the air was filled with dust 15 to 25 days of the month. The rains of May and June ameliorated the condition by settling the soil and promoting the germination of weed seeds. Weeds soon covered much of the soil with a green blanket. Stabilization was temporary and on many occasions dust storms of a local nature occurred in the dust bowl. While this catastrophe was greatest and most intensive during 1935 , it by no means constituted the only period when dust storms occurred.

During 1936, there was considerable soil movement in some sections of the western portion of the state.

4 During the great dust storm of March 20 to 22, 1935, the Department of Geology of the University of Wichita, at Wichita Kansas, "weighed" the atmosphere. They estimated that 5,000, 000 tons of dust were suspended over the area of 30 square miles occupied by the city in a layer of atmosphere one mile thick. However, the dust extended upward to a height of more than 12.000 feet and the source area of the dust was 250 miles west ward (Lugn. 1939). 
Much of the dust-blowing in cultivated fields subsequent to 1936 was prevented by improved cultural practices. On numerous occasions the writers have witnessed severe dust storms where the soil was actually lifted from prairies that were previously denuded by deposits of dust from cultivated fields. This type of dusting is difficult to control since cultivation, in many instances, is either undesirable or impossible (Joel, 1937).

\section{Evaporation}

The average monthly evaporation from a free water surface during the growing season for a period of 32 years (1907 to 1938) gradually increased from 5.9 inches in April to 10.5 in July, after which it decreased to 7.4 in September (Table 7). A total

TABLE 7. Average monthly evaporation in inches from a free water surface (1907 to 1938), and average deviation from the mean during the growing seasons of seven years of drought at Hays, Kansas.

\begin{tabular}{|c|c|c|c|c|c|c|c|}
\hline Year & April & May & June & July & Aug. & Sept. & Total \\
\hline $\begin{array}{l}\text { Av. } 1907 \text { to } 1938 \\
\text { inclusive ( } 32 \mathrm{yrs} \text { ) }\end{array}$ & 5.9 & 6.8 & 8.4 & 10.5 & 9.6 & 7.4 & 48.5 \\
\hline $1933 .$. & 6.9 & 7.0 & 12.9 & 12.4 & 8.9 & 8.4 & 56.5 \\
\hline 1934 & 7.0 & 10.8 & 12.6 & 16.3 & 13.1 & 6.6 & 66.4 \\
\hline $1935 \ldots \ldots \ldots \ldots$ & 7.3 & 5.5 & 6.9 & 13.1 & 11.3 & 7.5 & 51.6 \\
\hline $1936 \ldots \ldots \ldots \ldots$ & 7.3 & 6.8 & 10.1 & 14.6 & 12.1 & 8.0 & 58.9 \\
\hline $1937 \ldots \ldots \ldots \ldots$ & 6.8 & 8.4 & 9.9 & 11.5 & 11.3 & 7.9 & 55.8 \\
\hline $1938 \ldots \ldots \ldots \ldots$ & 5.2 & 4.7 & 7.7 & 11.2 & 12.4 & 7.8 & 49.0 \\
\hline $1939 \ldots \ldots \ldots \ldots$ & 5.9 & 9.5 & 11.3 & 13.6 & 9.8 & 10.8 & 60.9 \\
\hline $\begin{array}{l}\text { Deviation from } \\
\text { mean } \ldots \ldots \ldots \ldots\end{array}$ & +.7 & +.7 & +1.8 & +2.7 & +1.7 & +.7 & +8.5 \\
\hline $\begin{array}{l}\text { Av. 1933, 1934, } \\
1936,1939 \ldots \ldots\end{array}$ & 6.8 & 8.5 & 11.7 & 14.2 & 10.9 & 8.4 & 60.7 \\
\hline $\begin{array}{l}\text { Av. } 1935,1937 . \\
1938 \ldots \ldots \ldots \ldots\end{array}$ & 6.4 & 6.2 & 8.2 & 11.9 & 11.8 & 7.7 & 52.1 \\
\hline $\begin{array}{l}\text { Av. for } 1933 \text { to } \\
1939 \ldots \ldots \ldots \ldots\end{array}$ & 6.6 & 7.5 & 10.2 & 13.2 & 11.3 & 8.1 & 57.0 \\
\hline
\end{tabular}

of 48.5 inches was recorded for the entire growing season. The greatest seasonal evaporation during the drought period was 66.4 inches in 1934. This was followed by 58.9 inches in 1936 and 60.9 inches in 1939. The other extremely dry year, 1933, had a seasonal evaporation of 56.5 inches.

The greatest average monthly deviation from the mean occurred in July and was +2.7 inches. It was 1.8 inches above normal in June, 1.7 inches in $\mathrm{Au}$ gust, and 0.7 inch in each of the 3 remaining months, April, May, and September. Evaporation during the drought years was 8.5 inches above normal for the growing season. The average monthly evaporation for the 4 driest years was highest in July, being 14.2 inches. April had the lowest average evaporation which was 6.8 inches above normal. The average rate of evaporation for the 3 best years of the drought (1935, 1937, and 1938) was 6.4 inches during April, and 6.2 inches in May, after which it rose rapidly and reached its maximum of 11.9 inches in July.
Water Content of SoIL

The amount of moisture in the soil is especially important in the Great Plains region, since it is nearly always the limiting factor in plant production. Available soil moisture was determined in the first and second 6-inch depths and in 12-inch soil cores taken with a Briggs' geotome to a depth of 5 feet. Except for 1936, samples were obtained at weekly intervals from the third week of May to the second week of September throughout the entire period of drought. Other samplings were made at irregular intervals in early spring and in late fall. Total water content of soil minus the hygroscopic coefficient (which was determined for each soil depth) is designated as water available for growth. In this manner, the water content of soil upon which vegetation existed during the drought period was definitely ascertained (Fig. 8).

As a result of the wet year of 1932 , there was sufficient moisture stored in the soil of the shortgrass type of grassland to insure rapid growth in the early spring of 1933. Available water early in 1933 extended throughout the depth to which determinations were made. The top 12 inches contained more than 10 percent available water, and from the 12-inch depth to 3 feet, there was only slightly less. From the 3-foot level to 5 feet, nearly 5 percent of water was present.

As the season progressed, the quantity of available moisture rapidly diminished, especially in the upper portion of the soil. By the first week in June, no moisture was available in the first 12 inches; less than 5 percent was available in the second and fifth foot, and less than 2 percent in the third and fourth foot. By the second week in June, no moisture was available to 3 feet and less than 5 percent below that depth. This condition continued until the first week of July, with the exception of less than 2 percent in the first 6 inches during the third week in June, caused by local showers. During the second, third, and fourth weeks of July, from 8.3 percent to less than 2 percent was available in the upper 12 inches. During the first two weeks of August no moisture was available to a depth of 3 feet. Intermittent showers during the last half of August and the first half of September resulted in as much as 7.3 percent available moisture in the upper 6 inches. The amount of water between the 3- and 5-foot levels remained rather constant throughout the season, but at no time was the amount above 5 percent.

March and April of 1934 were unusually dry and by the third week of May there was less than 2 percent available moisture in the upper 6 inches and none below this depth to at least 5 feet. This condition remained constant until the third week of June, when approximately 5 inches of rainfall increased the amount of available moisture to 18.5 percent in the upper 6 inches and 12.8 percent in the second 6 inches. The increase in moisture in the second foot was almost negligible. This moisture was rapidly dissipated through evaporation and transpiration and lasted but 3 weeks. From the second 


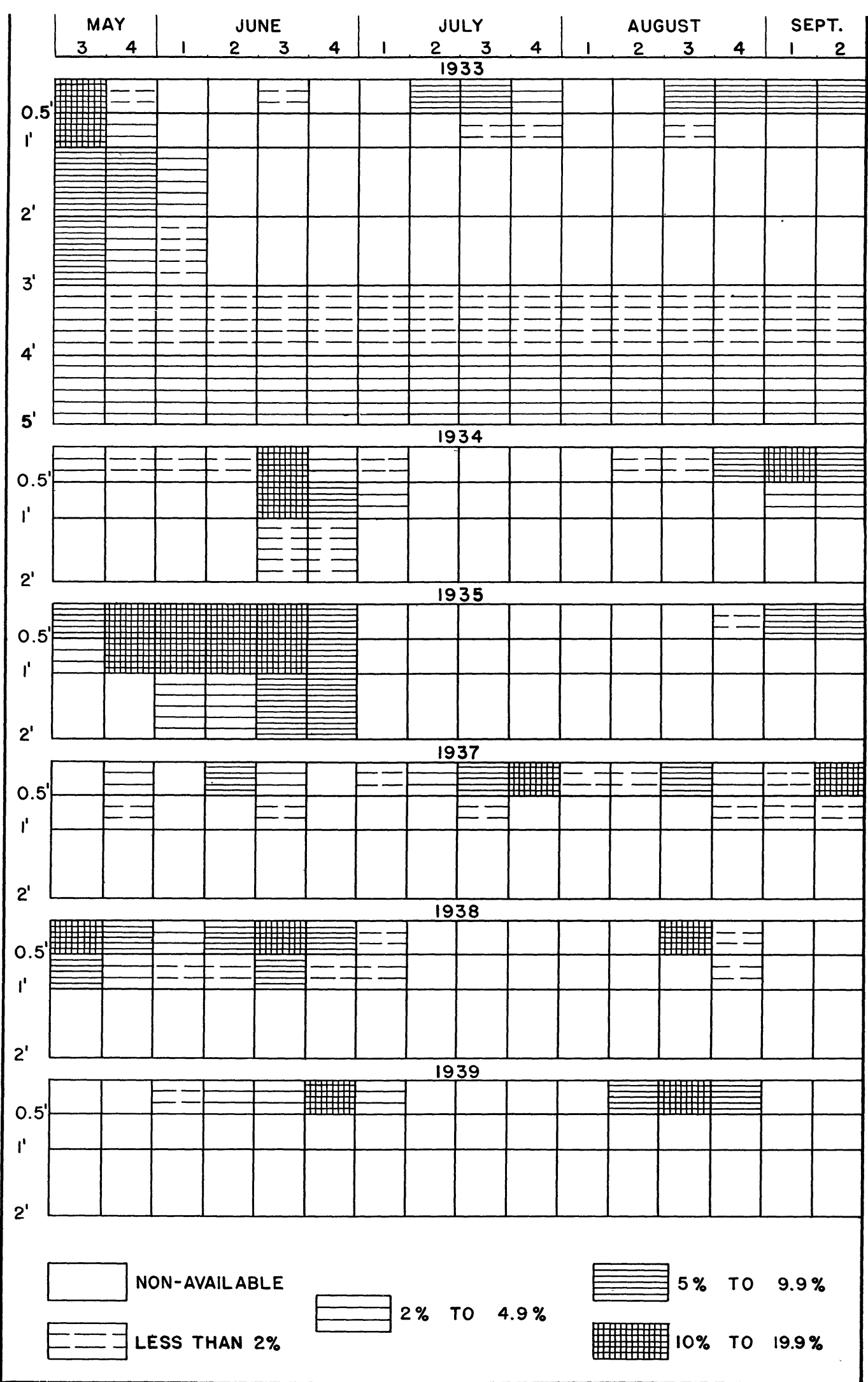

FIG. 8. Available soil moisture to a depth of 5 feet in short-grass (Buchloe-Bouteloua) habitat, Hays, Kansas. No moisture was available below 2 feet during 1934 to 1939 , inclusive, hence the 3 - to 5 -foot levels are not shown. 
week of July until the fourth week of August, there was no moisture available at any depth except in the upper 6 inches, where the amount was less than 2 percent. The rains during the latter part of August and early September brought the total available moisture to slightly more than $\mathbf{1 0}$ percent in the upper 6 inches. Less than 5 percent was available for plant growth in the second 6 inches and none below this depth. A small amount of available moisture in the upper 12 inches was present throughout the month of September, which gave the scanty stand of living vegetation an opportunity to produce some fall growth.

The early spring of 1935 was extremely dry and windy. Soil moisture determinations made during March and April showed that practically no available moisture was present during this time. The rains during the latter part of May and nearly all of June stored available moisture to a maximum depth of 24 inches. The greatest amount available at any one time was 14.7 percent in the upper 6 inches during the last week of May. This condition was maintained for 4 weeks, after which the available moisture rapidly diminished and for a period of 7 weeks during July and August there was none. Rainfall during late September, 1935, increased the amount of available moisture to 20 percent in the upper 6 inches.

The number of moisture determinations made during 1936 was insufficient to make it possible to include them in chart form. The amount of available moisture, however, was extremely low and where present was limited to the upper 6 inches.

There was no available moisture at any depth except the upper 12 inches in 1937. During 3 of the 16 weeks when moisture determinations were made, no available water was found at any depth. The amount present during the 13 weeks varied from 1.2 percent for the first week of July to 13.6 percent for the fourth week of the same month. The amount for the third week of August and the second week of September was 8.0 and 12.9 percent, respectively, in the upper 6 inches. Less than 2 percent was available in the 6- to 12-inch level during 6 of the 16 weeks and none was available during the remaining 10 weeks.

The nearly normal rainfall of 1938 failed to store available moisture in the soil to a depth greater than 12 inches. During the third week of May, 12.9 percent available moisture was found in the upper 6 inches and 5.8 percent in the second 6 inches. This supply gradually diminished until the showers during the third week of June restored the amount to 12.4 in the upper 6 inches and 5.7 in the second 6 inches. By the second week of July, all available moisture had been used by the growing vegetation. From this time until the third week of August, a period of 5 weeks, no available moisture was present. The rains during the third week of August, however, brought the total amount available to plant use up to $\mathbf{1 2 . 9}$ percent. Since this was all in the surface 6 inches, it was quickly lost through evaporation and transpiration.

There was never any available soil moisture below 6 inches during the extremely dry season of 1939. The amount in the upper 6 inches was never greater than 10 percent except during the fourth week of June and the third week of August. Less than 5 percent was present during 3 weeks of June and less than 10 percent during the second and fourth weeks of August. It is significant that even with showers as great as 1.5 inches, such as the one received on June 14, comparatively little water was stored in the soil. The explanation of this doubtless lies in the fact that much of a dashing rain of this amount, because of the relatively impervious soil and scarcity of vegetation, is lost to the location where it falls and becomes a flood hazard in the valleys below. Soil moisture determinations made later in the autumn of 1939 revealed that no moisture was available at any depth to 5 feet after August.

\section{COACTIONS}

Depletion of the ranges during drought has greatly intensified the grazing on practically all pasture land. The carrying capacity of large areas has been greatly reduced. Where formerly 1 animal unit required a grazing range of 10 to 12 acres, 30 to 50 acres are now needed. The farmers, in many instances, found it difficult to reduce the number of livestock to a conservative stocking rate; consequently, most of the grassland in the Great Plains region has been seriously overgrazed. Furthermore, decreased forage has caused a reduction in the quantity and quality of meat produced by the livestock. During recent years it has been impossible to earry livestock through the summer without supplemental feed.

Grasshoppers have further added to the deterioration of the range. On numerous occasions, as many as 8 to 12 per square foot have been found feeding upon the weeds and grasses in the native pastures. Preliminary investigations indicate that, during periods of extreme drought, a large percentage of the vegetation is consumed by the hungry grasshoppers.

\section{TYPES OF VEGETATION}

There are three types of vegetation, with varying degrees of intermixtures, that are common in the mixed prairie of west-central Kansas, especially in those regions where there is an outcrop of limestone, such as Smoky Hill Chalk, Fort Hays Limestone, and Benton Limestone (Fig. 9).

The little-bluestem (Andropogon scoparius) type is most extensive, occupying about 60 percent of the area. This type is commonly found on the hillsides and in shallow ravines. Under favorable environmental conditions, it extends over the brows of the hills and far into the short-grass areas if the slope is gentle. If the slope is steep, however, the transition from one type to the other is rather abrupt. 


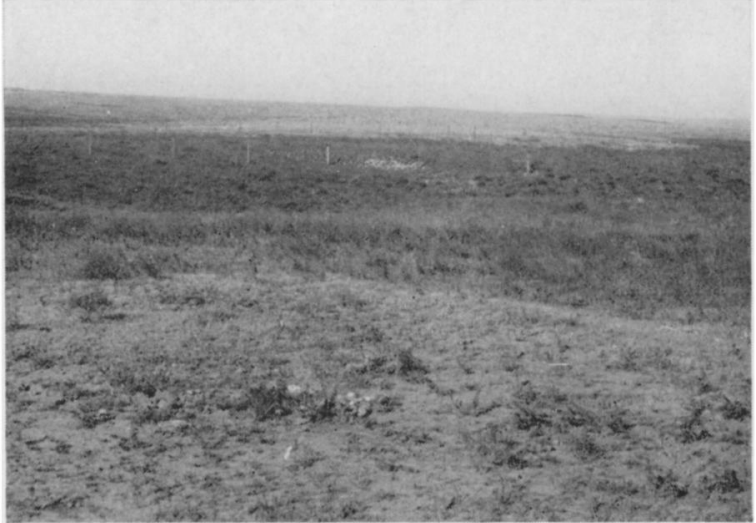

Fig. 9. Range land near Hays, Kansas, showing the Buchloe-Bouteloua type occupying the immediate foreground and distant background (light color), and the Andropogon scoparius type (dark) occurring in the ravine and on the slope. Photo, 1934 near Hays, Kansas.

The short-grass (Buchloe-Bouteloua) type constitutes approximately 30 percent of the prairies and is found widely distributed over the nearly level uplands. Smaller areas and strips also occur on gentle slopes and at the bases of hills, especially on southfacing slopes (Albertson, 1937). Farther to the southwest, where much of the land is comparatively level, the short-grass type predominates, and in many areas, due to overgrazing, the mid grasses have been almost completely replaced by the short grasses.

An ecotone or transition zone between the littlebluestem and short-grass types is composed of two layers of grasses, scattered bunches of little bluestem, wire grass (Aristida spp.), and side-oats grama (Bouteloua curtipendula) forming the upper laver and the short grasses the lower one.

The big-bluestem (Andropogon furcatus) type is of much less importance and is generally limited to the larger ravines and protected slopes (Clements, $1936)$.

\section{CHANGES IN VEGETATION}

Vegetation that has become adapted to the variable climatic conditions in the Great Plains region has been compelled to undergo a state of dormancy or semidormancy several times during the growing season. During the period of 7 vears of drought, the vegetation has frequently been subjected to such severe desiccation that for davs at a time much wilting occurred. Often buffalo grass (Buchloe dactyloides), blue grama grass (Bouteloua gracilis), and even other species became so dry that when trodden upon they crackled underfoot (Shantz, 1923).

Short grasses growing on the tablelands were the first to manifest effects of drought. The ordinary straw color accompanying dormancy usually appeared several times during the season, but in 1934 and 1939 much of the vegetation became bluish-gray, a color indicative of death. Many mesic plants disappeared completely and were replaced by others less

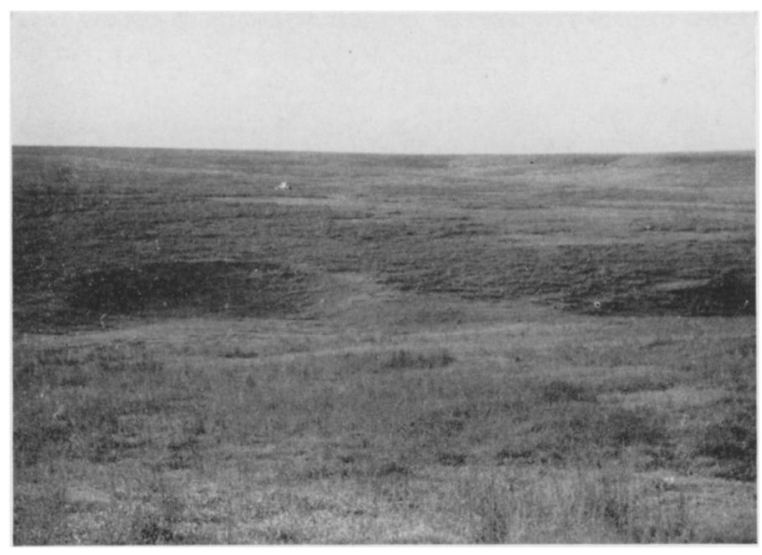

Photo by L. D. Wooster

Fig. 10. Andropogon scoparius type (dark areas) and Buchloe-Bouteloua type (light areas) occupied the gentle slopes in 1930 before the drought. Photo in 1930 near Hays, Kansas.

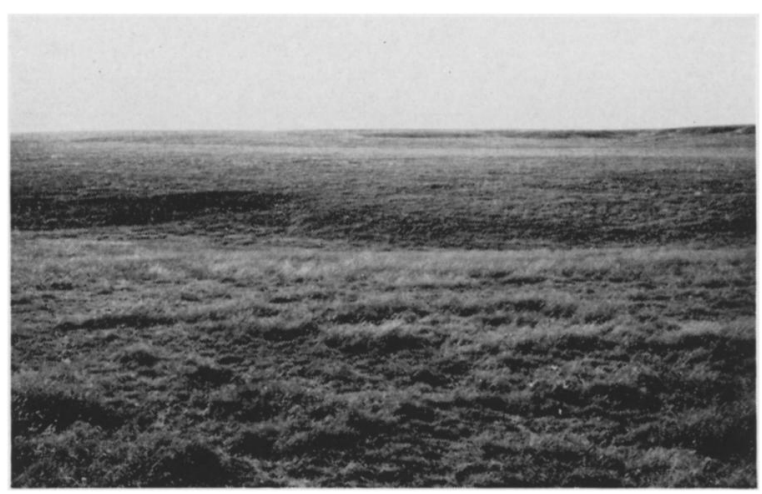

Fig. 11. View of the same general area as shown in Fig. 10 as it appeared in May of 1939, after 7 years of drought. A sparse cover of short grasses has replaced the little bluestem. Hays, Kansas.

susceptible to drought. Even the more xeric were often very much reduced in numbers (Figs. 10 and 11) (Albertson, 1938; 1939).

Animal life was materially affected by drought and dust. This was especially true of the ground-dwelling species of mammals and birds. The number of jack rabbits, prairie chickens, quails, and horned larks, for example, was reported to have been greatly reduced in some areas (Wooster, 1935; 1939). The destructive effect of drought on the vegetation upon which they fed has been traced annually by means of scores of permanent quadrats.

\section{Changes in Andropogon scoparius Type}

Studies in the Andropogon scoparius type were begun in 1932 when stock was excluded from several representative areas, which had been moderately grazed for many years. Numerous meter quadrats were staked out and permanently marked for future study. These quadrats were charted in the fall of 1932 and each subsequent autumn except 1936. 
UNGRAZED CLOSED TYPE OF ANDROPOGON SCOPARIUS

The percentage of basal cover afforded by each species for each year in this type is shown in Table 8 .

TABLE 8. Change in percentage of basal cover in 15 meter quadrats in an ungrazed, closed type of Andropogon scoparius at Hays, Kansas, from 1932 to 1939. The data are from two groups of quadrats but the response of the vegetation is similar in both.*

\begin{tabular}{|c|c|c|c|c|c|c|c|}
\hline Species & 1932 & 1934 & 1935 & 1936 & 1937 & 1938 & 1939 \\
\hline Andropogon scoparius. . & 49.6 & 37.2 & 9.6 & 3.5 & 1.4 & .9 & 6 \\
\hline Andropogon furcatus. & 10.7 & 5.5 & 8.5 & 4.6 & 5.3 & 3.2 & 2.2 \\
\hline Bouteloua curtipendula... & 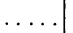 & 3.1 & 6.1 & 6.2 & 12.1 & 17.7 & 17.6 \\
\hline Bouteloua gracilis. & & .7 & 2.1 & 1.8 & 5.6 & 7.8 & 8.8 \\
\hline Bouteloua hirsuta... & $\ldots$ & .4 & .3 & & .3 & .3 & .3 \\
\hline Sporobolus pilosus.. & $\ldots$ & $\ldots$ & .1 & .0 & .3 & .4 & .4 \\
\hline Buchloe dactyloides. . & $\ldots$ & . & $\cdots$ & .. & $\ldots$ & .1 & .3 \\
\hline Total. & 60.3 & 46.9 & 26.7 & 16.1 & 25.0 & 30.4 & 30.2 \\
\hline
\end{tabular}

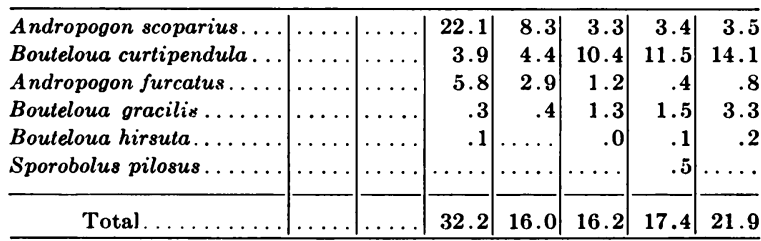

*Forbs are not included in this paper because of limitations of space they will be treated separately. The presence or absence of ruderals at the time of quadratting was largely determined by variations in seasonal conditions. Native forbs have been greatly depleted in numbers or have disappeared.

Little bluestem constituted the major portion of the vegetation when these studies were initiated (Fig. 12). Its associate, big bluestem, formed approximately one sixth of the total plant cover. The basal cover averaged about 60 percent. Less than this amount was frequently found because of excessive debris resulting from dead vegetation accumulated through previous years. Slight increases occurred where grazing was heavy enough to prevent this accumulation but not so intense as actually to damage the bluestems.

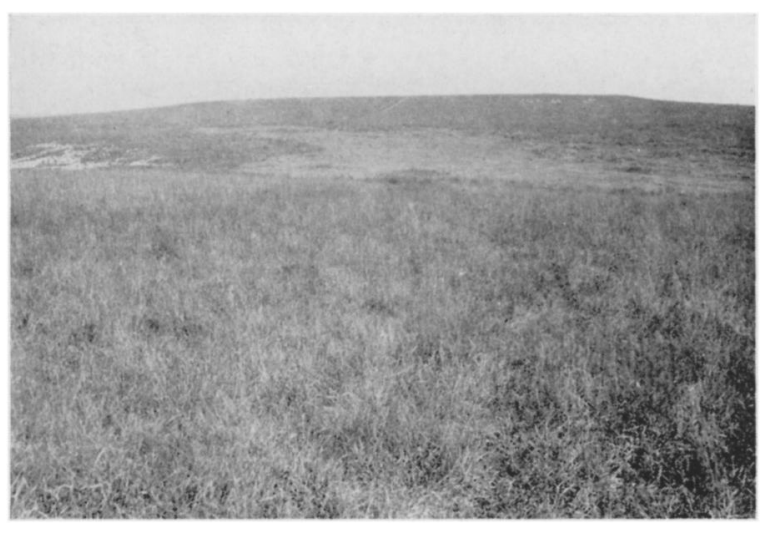

Photo by L. D. Wooster

Fig. 12. Typical Andropogon scoparius type of grassland at Hays, Kansas.

The average basal cover of nine quadrats was gradually reduced from 60.3 percent in 1932 to a minimum of 16.1 percent in 1936. The somewhat better years of 1937 and 1938 brought some improvement. The basal cover was increased to 25 percent in 1937 , to 30.4 in 1938, and to 30.2 percent in 1939 . It is evident that the accumulated benefits derived from the nearly normal year of 1938 earried over into 1939, when the rainfall was the least of any year during the entire period of drought. The shifting of the various plant species is shown in Figure 13.

The characteristic appearance of the ungrazed little-bluestem type which prevailed during the period of favorable growing conditions was gradually but definitely lost soon after the onslaught of the drought, which began in 1933. The dried tops of little bluestem of 1932 showed clearly that under favorable conditions this grass reaches a height of about 2 feet. Growth during 1933 was irregular and seldom approached normal except in certain favored places where there was more available moisture than
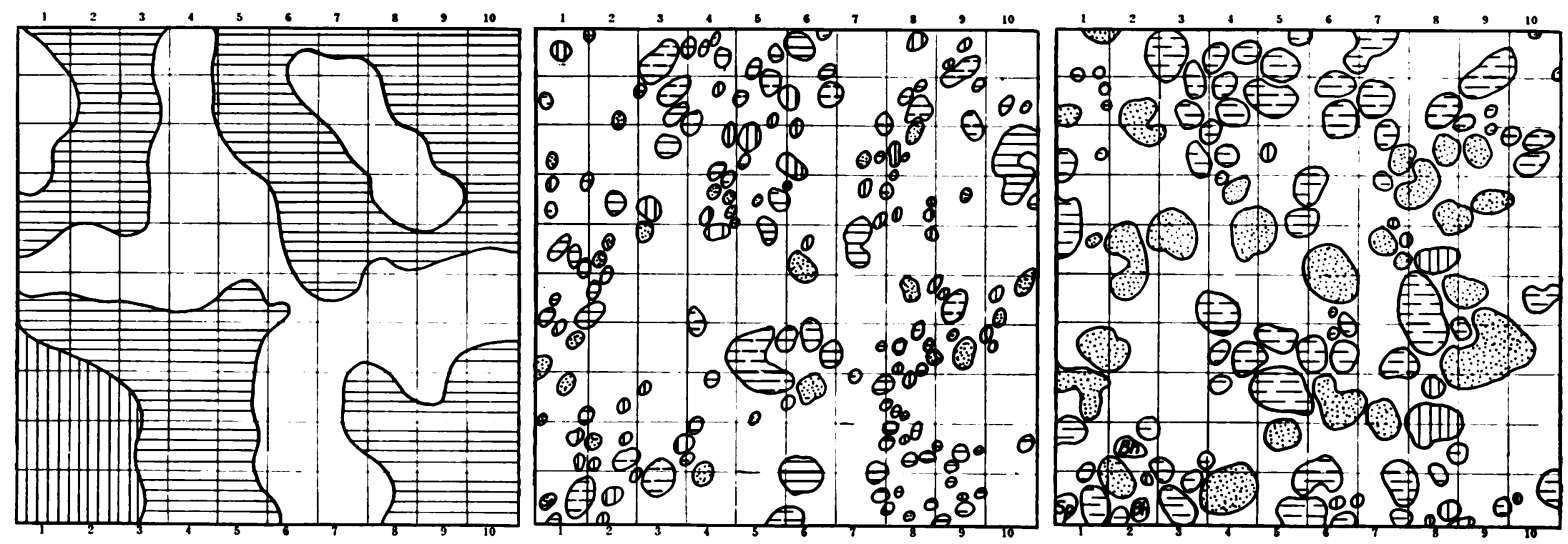

Fig. 13. Quadrat in an ungrazed, closed type of Andropogon scoparius charted in the fall of 1932 (left), 1936 (center), and 1939 (right). In 1932 Andropogon scoparius (horizontal hatch) had a basal cover of 67.5 percent. The cover of Andropogon furcatus (vertical hatch) was 7.7 percent. The bluestems were replaced primarily by Bouteloua curtipendula (broken horizontal hateh) and Bouteloua gracilis (small dots). Hairy grama (Bouteloua hirsuta) (Bh), and hairy dropseed (Sporobolus pilosus) ( $\mathrm{Sp}$ ) were never abundant. The open space is bare ground. The large amount of open, space (not hatched) in 1932 (24.8 percent) was due to previous excessive debris. That in 1936 (85.5 percent) and 1939 (68.2 percent) resulted in the main from drought. 
was found elsewhere. By the middle of June, 1933, this chief dominant had grown but little, and the folded leaves were a definite sign of drought. The more deeply rooted big bluestem, however, was from 9 inches to 15 inches tall and apparently little affected by drought.

By the first of July, there was no available moisture ${ }^{5}$ in the upper 24 inches and many of the grasses were showing more definite signs of soil moisture deficiency. Only the deeply rooted forbs such as lead plant (Amorpha canescens) and few-flowered psoralea (Psorulea tenuiflora) were fresh and green.

The early spring of 1934 was unusually dry and renewal of growth was much delayed. The rains of June, however, did much to revive the droughtstricken vegetation, and growth continued until early in July when, because of extreme heat $\left(112^{\circ} \mathrm{F}\right.$.), low relative humidity (9 percent), and deficient soil moisture, much of the vegetation in this habitat was forced into dormancy. This condition continued until the slightly above normal precipitation of September stimulated some fall growth. It was observed during the fall of 1934 that many of the young native plants, both grasses and forbs, and the older bunches of grass, had suffered severely from drought. The basal cover had decreased from 60.3 percent to about 47 percent.

The heary rains of late May and early June of 1935 washed away much of the dust that had accumulated on the vegetation in this habitat. Vegetation that remained after 2 years of drought and a severe dusting renewed growth with much vigor during June when the surface soil was continuously moist. The supply of available soil moisture, however, was soon exhausted and by the middle of July the little bluestem, now 12 inches high, began to wilt and was soon forced into dormancy. The effects of drought became much more intense on south-facing slopes than on those facing northward. Furthermore, the xeric strips of short grasses commonly found on the lower slopes, with bluestems both above and below (Albertson, 1937), became widened by short grasses invading the vegetation both above and below their usual habitat. ${ }^{6}$

The accumulated effects of 1933,1934 , and 1935, added to the extremely dry year of 1936 , was nothing less than a catastrophe to the bulk of the living plants. The rains of Mav (1936) were sufficient to support growth for only a few weeks, after which the extremely dry weather of June and July reduced the hasal cover to 16.1 percent. This was scarcely more than one fourth the original amount (Fig. 14).

Even though the rainfall for the vear 1937 was somewhat greater than for three of the four preceding ones, the amount received during the growing season was below normal in every month except July. It was the rainfall of July and August that caused

: Soil moisture determinations were regularly made in the little-bluestem and big-bluestem habitats during 1933 and inter mittently thereafter. These data, however, are not included in chart form.

CThe narrow strips of short grasses on the lower slopes are usually underlaid with a highly impervious clay soil which has resulted from disintegrated shale.

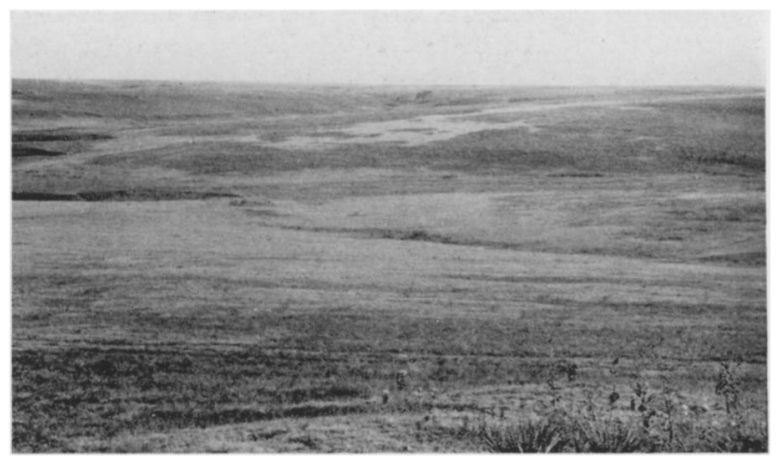

Fig. 14. Andropogon scoparius on a gentle slope on a range near Hays, Kansas, in 1936. The open sod in the foreground was caused by 4 years of drought. The short grasses (light) have replaced much of the little bluestem.

late summer growth, which in turn resulted in a slight increase in cover over that of the previous year.

The rains of April and May of 1938 were conducive to both the germination of seed and the rapid growth of the living portion of native plant cover. Remnants of little bluestem were found only rarely where the continued drought had failed completely to destroy them. Big bluestem was also found to contain small live fragments scattered sparsely through the area which it originally occupied.

Myriads of seedlings appeared in the open spaces between the bunches of living grasses. On numerous occasions, as many as 50 to 75 per square foot, mostly those of side-oats grama and hairy grama, were found. These seedlings were of greatest abundance near the parent plants where the soil surface was protected from drying dur'ng the period of seed germination. The drought of July and early August greatly reduced the number of live seedlings. It was not uncommon to find numerous seedlings with 3 to 5 brown leaves that had withered and fallen. Examination revealed that the roots had penetrated less than 12 inches into the soil, which now had no available moisture. It was estimated that 90 percent of the seedlings perished during this dry period.

The mature vegetation fared considerably better than did the seedlings. The clay pockets in the rock crevices between the 2 - and 8 -foot depth were well supplied with moisture by the spring rains. This supply was sufficient to support rather continuous growth throughout the season. By August most of the grasses were fruiting. The effects of the drought were manifest, however, in the small percentage of carvopses produced in relation to the number of florets. The adverse growing conditions were most intense in 1938 during the time when many of the grasses were in full blossom. This condition was doubtless instrumental in reducing the vield of caryopses to almost zero in many locations. It is significant that the best yields of seed were obtained in buffalo wallows, on north-facing slopes, and in similarly better-watered places.

The year of 1939 was the driest of all during this drought period. The rains of June and August were 
slightly above normal. But being separated by the hot, dry month of July, the rainfall of June, in particular, was relatively ineffective. Showers in August, however, aided materially the struggling grasses in producing flower stalks and, in a few cases, an extremely low percentage of caryopses. The reserve of soil moisture carried over from 1938 plus the small amount received during the growing season of 1939 was sufficient to maintain the basal cover of approximately 30 percent produced during the previous year (Fig. 15).

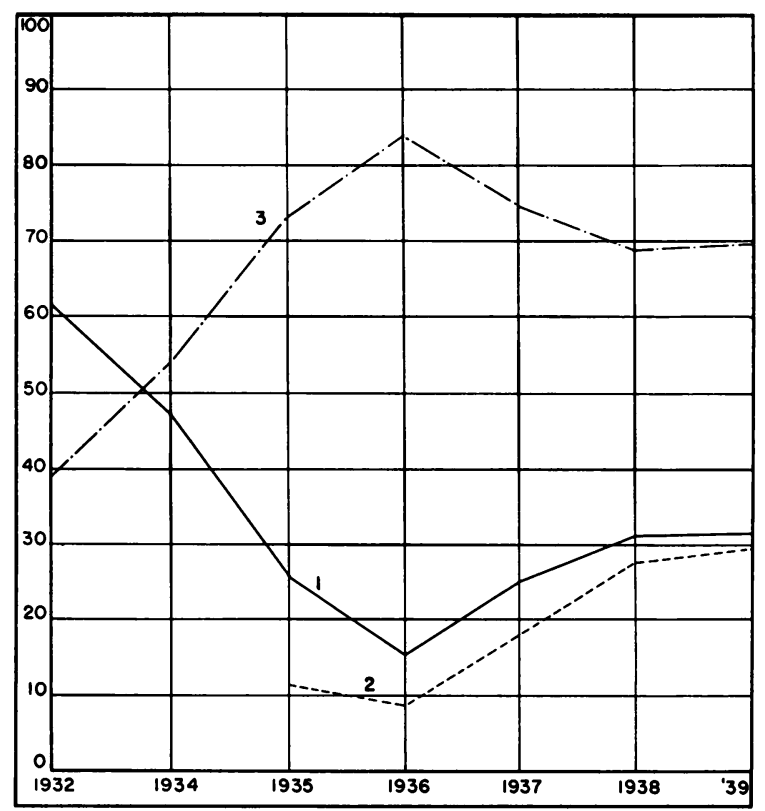

Fig. 15. Graphs showing the percentage of basal cover during the several years of drought in (1) ungrazed and (2) overgrazed Andropogon scoparius type. The percentage of bare ground is shown by graph 3 .

A decrease in the basal cover and a corresponding increase in bare ground were not the only things of interest that occurred during these 7 years. The direction of movement of all vegetation was toward locations where environmental conditions, especially soil moisture, were more conducive to plant growth.

Little bluestem, which furnished the major portion of vegetation at the beginning of the drought, rapidly decreased to practically nil by 1939. Large areas of comparatively level pastures were often found to be completely devoid of this species. Sometimes a few dwarfed, weak stems grew from the periphery of some of the nearly dead bunches.

Big bluestem, though it suffered severe losses, survived better than its associate. This was attributed, in part, to the greater depth to which its roots penetrated but also to the considerable quantities of reserve food in the crowns and rhizomes which occupied a large portion of the soil. This stored food was doubtless of great value in maintaining life at low ebb during periods of most severe drought. The average basal cover of this species was 10.7 percent in 1932. Loss was continuous but irregular throughout

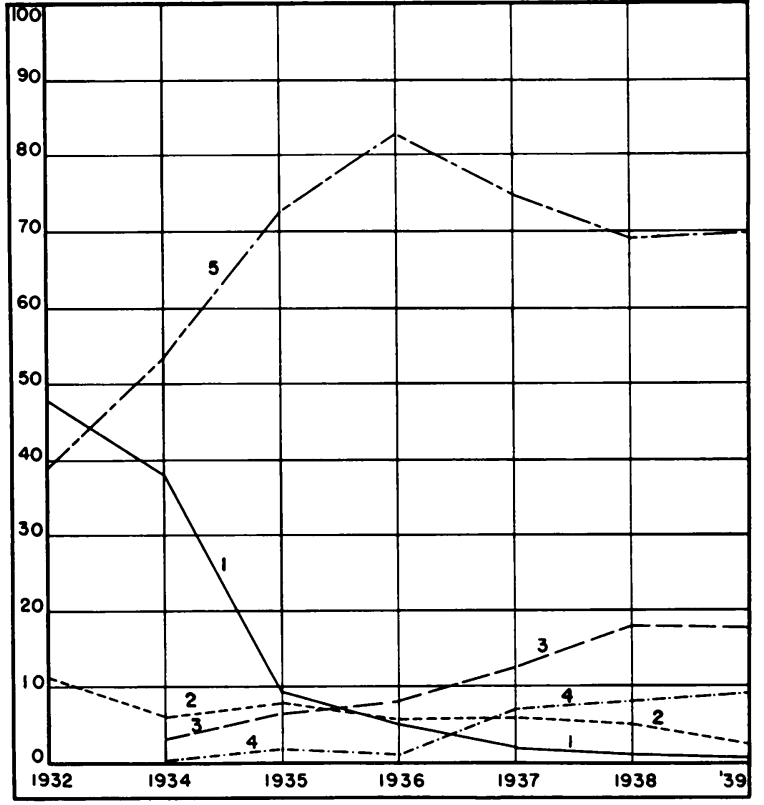

Fig. 16. Percentage of basal cover of various grasses in the ungrazed Andropogon scoparius type. (1) Little bluestem and (2) big bluestem were the only grasses present in 1932. (3) Side-oats grama and (4) blue grama were first found in 1934 . The percentage of bare ground (5) reached its maximum in 1936.

the drought period, and in 1939, only an average cover of 2.2 percent remained.

Side-oats grama, being more xeric than the bluestems, spread considerably and occupied a portion of the soil bared by the death of the bluestems (Table 8 and Fig. 16). This grass first appeared in the quadrats in the fall of 1934 in an abundance of only 3.1 percent. It is significant that thereafter the increase was continuous, and by 1938 this species constituted over half the vegetation (Fig. 17). Observations showed that much of the increase accrued from new plants produced from the numerous rhizomes 1 to 5 inches long which radiated in all directions from the margins of the parent plants. Such young shoots survived drought much better than did seedlings. In

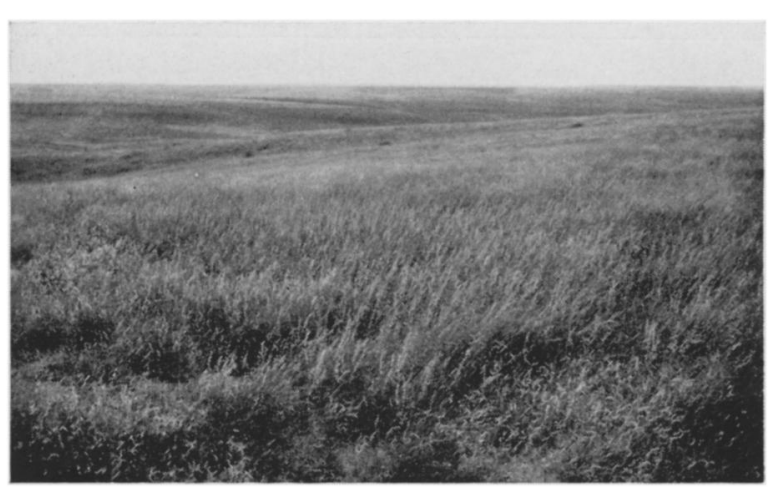

Fig. 17. Area once occupied by little bluestem. After 7 years of drought, side-oats grama and blue grama constituted most of the cover. Photo, 1939, Hays, Kansas. 
fact, it was found that when death occurred in this species, it was usually the center of large clumps that died rather than the younger plants produced from rhizomes.

Blue grama, which also made its first appearance in 1934, spread downward from the Buchloe-Bouteloua disclimax above. Increase in number of plants was accomplished by the development of seedlings but increase in size results from addition of new tillers at the periphery of the bunches. This species occupied less than 1 percent of the area in 1934. It scarcely showed consistent gains until 1937. It had increased to 2.1 percent in 1935 but decreased to 1.8 percent in 1936. Thereafter small gains were gradual but constant. In 1939 the average basal cover was 8.8 percent.

\section{UNGRAZED OPEN TYPE OF ANDROPOGON SCOPARIUS}

The most common vegetation on the brows of the hills, where the underlying limestone is at or near the surface, is of the open-bunch type. It was not unusual to find only a few scattered tufts of little bluestem, hairy grama, and hairy dropseed, with a considerable sprinkling of dwarfed forbs, in the open spaces between the bunches. Due to the sparseness of vegetation and the frequent mulch of partially disintegrated fragments of limestone, it seems probable that depletion of soil moisture through transpiration and evaporation from the soil surface occurs more slowly than from the more densely populated, deeper soil.

In 1932 the average basal cover of a group of several representative quadrats was 25.5 percent (Table 9). The loss of the dominant was negligible

TABLE 9. Change in percentage of basal cover in an ungrazed open type of Andropogon scoparius at Hays, Kansas.

\begin{tabular}{|c|c|c|c|c|c|c|c|}
\hline Species & 1932 & 1934 & 1935 & 1936 & 1937 & 1938 & 1939 \\
\hline Andropogon scoparius. & 25.3 & 23.4 & 11.4 & 7.3 & 4.3 & 6.4 & 5.6 \\
\hline Bouteloua curtipendula. & $\ldots$ & 2.2 & 1.1 & 3.9 & 8.1 & 10.7 & 11.1 \\
\hline Bouteloua hirsuta.. & .2 & .9 & .2 & .5 & .7 & 1.3 & 1.2 \\
\hline Andropogon furcatus. & 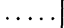 & .3 & .4 & . & .3 & .3 & $\cdots$ \\
\hline Sporobolus pilosus. & 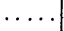 & . & $\ldots \ldots$ & .1 & .2 & .2 & .2 \\
\hline Total & 25.5 & 26.9 & 13.1 & 11.8 & 13.6 & 18.9 & 18.1 \\
\hline
\end{tabular}

during 1933 and 1934; there was a slight gain in the total cover due to an increase in other grasses. The effects of the drought were first apparent in 1935 when the total cover was reduced to 13.1 percent. This was further decreased to 11.8 percent in 1936 , after which there was a gradual increase to a maximum of 18.9 percent in 1938. There was a loss of less than 1 percent in 1939.

The relative degree of drought resistance of little bluestem and side-oats grama was clearly shown in comparing the reaction of each to its environment through the 7 years of drought. Little bluestem, which made up practically all the vegetation when the studies were begun in 1932, rapidly diminished until 1937 when a minimum cover of 4.3 percent was reached. The gain during 1938 and 1939 was small. Side-oats grama, on the other hand, gained rather steadily after its appearance in 1934 and constituted over 60 percent of the total vegetation in 1939 .

OVERGRAZED CLOSED TYPE OF ANDROPOGON SCOPARIUS

Studies in the overgrazed little-bluestem type were begun in 1935, when the total cover had been reduced to only 11.5 percent (Table 10). The average cover

TABLE 10. Change in percentage of basal cover in 8 meter quadrats in an overgrazed closed type of Andropogon scoparius at Hays, Kansas.

\begin{tabular}{|c|c|c|c|c|c|}
\hline Species & 1935 & 1936 & 1937 & 1938 & 1939 \\
\hline Andropogon scoparius......... & 3.1 & 1.4 & .8 & .5 & .2 \\
\hline Andropogon furcatus. . . . . . . & 1.4 & 1.7 & 1.6 & 3.3 & .7 \\
\hline Bouteloua curtipendula........ & 3.4 & 3.3 & 7.7 & 11.5 & 12.1 \\
\hline Bouteloua gracilis.............. & 2.9 & 1.8 & 4.8 & 6.4 & 7.9 \\
\hline Bouteloua hirsuta.............. & .6 & .4 & 1.1 & 1.0 & 2.1 \\
\hline Buchloe dactyloides............. & $\ldots$ & .3 & .5 & 3.2 & 4.3 \\
\hline Sporobolus cryptandrus......... & .1 & .1 & .6 & .6 & 1.4 \\
\hline Aristida purpurea. ........... & $\cdots$ & .3 & 1.4 & 1.2 & .8 \\
\hline Total. & 11.5 & 9.3 & 18.5 & 27.7 & 29.5 \\
\hline
\end{tabular}

for any one species did not exceed 3.4 percent, and the lowest cover for any of the five most persistent species was 0.6 percent.

No quantitative determinations were made of the cover of the various grasses in this type before the drought, but notes from studies made on various occasions indicate that the total cover was only slightly less than on the ungrazed area. Due to reduced root extension and food storage in the crowns, the dominants under heavy grazing were unable to cope with drought as efficiently as when ungrazed. The reduced stature of the bluestems from grazing doubtless made possible the successful invasion of the short grasses such as blue grama, hairy grama, and buffalo grass. Even sand dropseed (Sporobolus cryptandrus) and wire grass became fairly well established in many of these areas (Fig. 18). The minimum cover of 9.3 percent was reached in 1936 . The cover was practically doubled by 1937 , and by 1939 it had reached 29.5 percent or more than three times that of 1936 .

The two bluestems continued to decrease until their total cover was less than 1 percent in 1939. The increase of the more xeric grasses, side-oats grama, blue grama, hairy grama, and even buffalo grass, accounted for most of the gain. Side-oats grama, for instance, had 3.4 percent cover in 1935 , but this had increased to 12.1 percent by 1939 . Similar increases, though in smaller amounts, occurred in the other more xeric species.

\section{Changes in Buchloe-Bouteloua Type}

These studies were begun in 1932 when several exclosures were made and numerous representative square meters selected for long-time study. They were extended in 1935, following 2 years of drought and a spring of exceptionally heavy dusting. It was at this time that areas ungrazed for many years, 

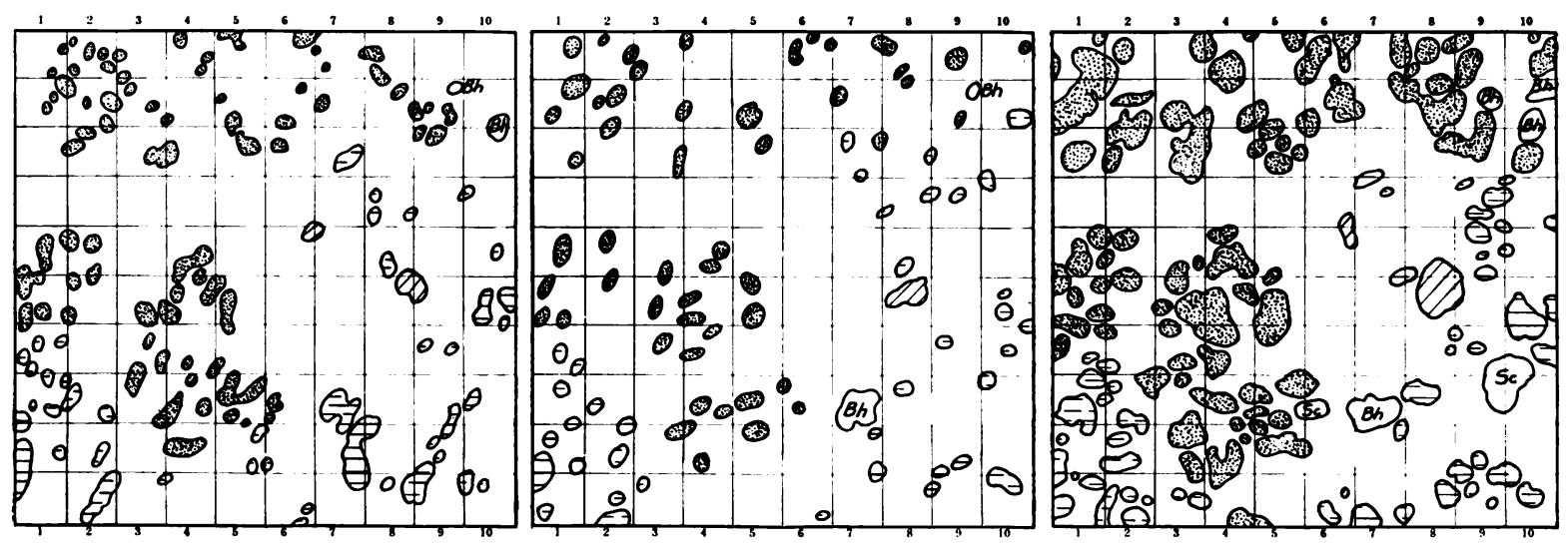

Fig. 18. Typical quadrat in overgrazed closed-type of Andropogon scoparius charted in 1935 (left), 1936 (center), and 1939 (right). Much of the little bluestem (horizontal hatch) had been killed by 1935 when its cover was only 1.8 percent. The space left bare by this grass was partially occupied by blue grama (small dots) and side-oats grama (broken horizontal hatch). Hairy grama (Bh) is also common in this location. Aristida longiseta (diagonal hateh) was present in only a small amount (0.4 percent) in 1935 . Blue grama made steady gains under the influence of overgrazing and drought and had a cover of over 16 percent in the autumn of 1939. Sporobolus cryptandrus (Sc) invaded many of the open places during the drought.

some moderately grazed, and others that were overgrazed, were included.

The area of study was greatly increased in 1937. Quadrats were established to a distance of more than 200 miles southwest of Hays. The new pastures represented four general conditions: namely, lightly dusted and moderately grazed, lightly dusted and overgrazed, heavily dusted and lightly grazed, and heavily dusted and overgrazed.

\section{UNGRAZED BUCHLOE-BOUTELOUA TYPE}

The pasture under study in 1932 had been moderately grazed, but was thereafter protected from grazing. Determinations as to the relative proportion of the two dominants, blue grama grass and buffalo grass, were made in 1931 and 1932. They occurred in about equal abundance. As shown in Table $11 \mathrm{~A}$, the basal cover was 88.6 percent (Fig. 19). After 2

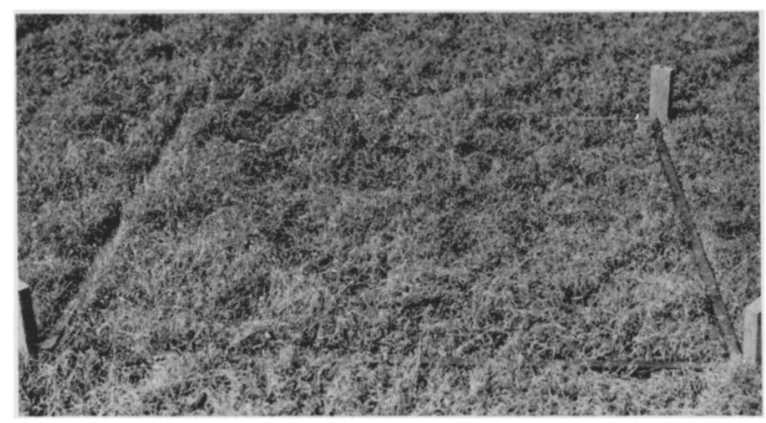

Fig. 19. Quadrat in the closed blue grama-buffalo grass type, typical of the short grasses in 1932 when they were only moderately grazed. The basal cover is 88.6 percent.

vears of drought (1933 and 1934), the basal cover had been reduced to 84.7 percent. By 1935, the cover was further reduced to 65.4 percent and then to 57.7 percent in 1936. Thus, during the first 4 years of drought, reduction in basal cover was fairly slow.
TABLE 11. Change in percentage of basal cover in 10 meter quadrats in typical areas of the ungrazed BuchloeBouteloua type at Hays, Kansas.

\begin{tabular}{|c|c|c|c|c|c|c|c|}
\hline Species & 1932 & 1934 & 1935 & 1936 & 1937 & \begin{tabular}{|l|}
1938 \\
\end{tabular} & 1939 \\
\hline $\left.\begin{array}{l}\text { Buchloe dactyloides... } \\
\text { Bouteloua gracilis.... } \\
\text { Aristida purpurea .... }\end{array}\right\}$ & 88.6 & $\begin{array}{r}83.7 \\
1.0\end{array}$ & \begin{tabular}{r|}
64.9 \\
.5 \\
\end{tabular} & 57.7 & $\begin{array}{r}8.7 \\
15.8 \\
.2\end{array}$ & \begin{tabular}{|l|}
15.6 \\
15.0
\end{tabular} & $\begin{array}{r}9.3 \\
13.0 \\
\ldots \ldots\end{array}$ \\
\hline Total. & 88.6 & 84.7 & 65.4 & 57.7 & 24.7 & 30.6 & 22.3 \\
\hline
\end{tabular}

\begin{tabular}{|c|c|c|c|c|c|c|c|}
\hline Spccies & $\underset{1935}{\text { Spring }}$ & 1935 & $19: 6$ & $\underset{19: 7}{\text { Spring }}$ & $19: 7$ & 1938 & 1939 \\
\hline Bouteloua gracilis. & 20.3 & 18.9 & 9.1 & 13.8 & 16.1 & 23.4 & 21.1 \\
\hline Buchloe dactyloides. . & 3.9 & 3.8 & 1.1 & 1.2 & 1.8 & 2.8 & 4.5 \\
\hline Sporobolus cryptandrus. & .5 & .1 & .0 & .3 & .3 & $\therefore$ & .3 \\
\hline Aristida purpurea . . . . & .2 & .3 & .4 & $\ldots$ & & & \\
\hline Agropuron smithii.... & .4 & .2 & & .1 & & & \\
\hline Total & 25.3 & $23 . \dot{s}$ & 10.6 & 15.4 & 18.2 & 26.5 & 25.9 \\
\hline
\end{tabular}

The accumulated results of the drought produced the greatest breakdown in the cover between 1935 and 1937 , and a cover of approximately 25 percent was reached in the fall of 1937 . The amount increased to 30.6 percent in 1938 due to better growing conditions, but the drought of 1939 caused another decrease, and when charted in the fall only 22.3 percent of cover remained (Fig. 20) (Savage and Jacobson, 1935).

The basal cover of the vegetation on another area that had been ungrazed for many years before 1935 was significantly less than where moderate grazing was practiced prior to initiating this study (Table 11B). The excessive growth of the ungrazed vegetation during the favorable years evidently caused the grasses to be more susceptible to drought injury than were the moderately grazed ones. 

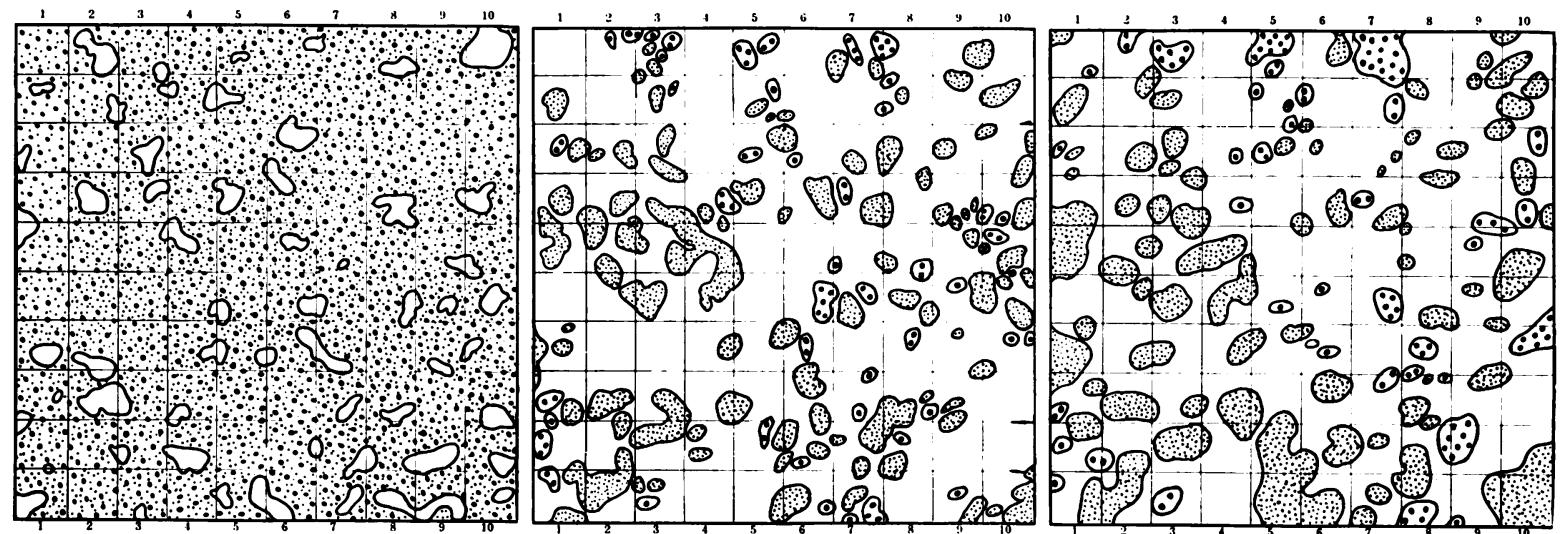

Fig. 20. Typical quadrat in ungrazed short-grass type with a dense cover, charted in the fall of 1932 (left), 1937 (center), and 1939 (right). Buffalo grass and blue grama grass were not charted separately in 1932; basal cover of the mixture was 89.5 percent. In 1937, the cover of buffalo grass (large dots) was 4.5 percent and that of blue grama grass (small dots) 16.2 percent. By 1939 the cover of these grasses had increased to 5.8 and 21.0 percent, respectively.

In the spring of 1935, the average basal cover was only 25.3 percent, most of which was blue grama. Buffalo grass, which had doubtless suffered greatest injury from drought, constituted only 3.9 percent of basal area. The remaining portion was divided among Sporobolus cryptandrus, Aristida purpurea, and western wheat grass (Agropyron smithii). Only a slight decrease occurred during the summer of 1935 and when charted in the fall the average cover was 23.3 percent. The greatest loss occurred between the fall of 1935 and that of 1936 , when the cover was reduced to 10.6 percent.

Farly spring growth in 1937 increased the cover to 15.4 percent but this amount was further increased to 18.2 percent during the remainder of the season. The cover was extended to 26.5 percent in 1938 and only slightly reduced during the season of 1939 .

Comparisons made in other short-grass areas that were ungrazed indicated that in some instances the cover had increased to a percentage somewhat greater than that shown in Table 11 . The ravages of the drought caused a great variation in the density of the vegetation. In some places, there occurred large barren areas almost devoid of plants. Hence, the numbers given in the table would seem to be somewhat below the average for 1938 and 1939 (Fig. 21).

The first signs of drought were observed early in June of 1933 when the immature staminate blossoms of buffalo grass were greatly damaged, and its leaves were spirally coiled and dead at the tips. The leaves of blue grama grass, though dark green in color, were rolled. They closely resembled those of Aristida. The immature inflorescences of squirreltail (Sitanion Mystrix) were blasted by excessive heat. By June 15, the buffalo grass had become dormant in local areas where the supply of water was least. Elsewhere, however, the natural green color of the leaves was retained. Nearly all the blue grama and buffalo grass was dormant by July 1 . The scattered bunches of l:ttle bluestem, wire grass, and squirreltail were badly withered and in many instances were nearly dead.

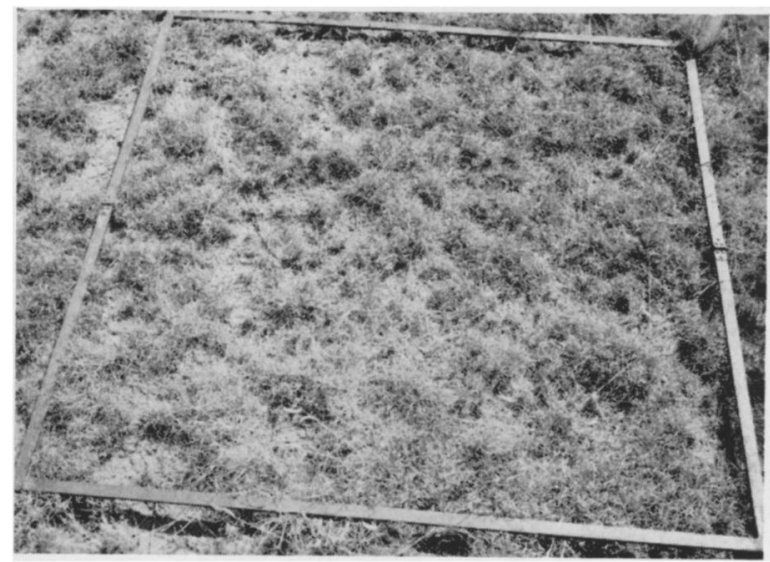

Fig. 21. View of ungrazed short grasses at Hays, Kansas, in 1939. The living basal cover has been reduced, during the past 7 years, to less than 30 percent.

A few scattered showers early in July supplied some available moisture for plant growth. Many of the grasses showed signs of life, especially in shallow depressions. Green color was restored in some instances where the leaves had not gone into complete dormancy. Usually, however, new leaves emerged from the crown, which was protected by the dormant vcgetative cover; in fact, careful observations revealed that even in the periods of greatest drought small amounts of the crown remained green. Sufficicnt soil water was present during the third and fourth weeks of July to promote considerable plant growth. The small amount of moisture, however, was soon exhausted and by August 5, the grasses were again dormant. Growth was renewed late in August when the soil was moistened to a depth of approximately a foot.

Renewal of growth eame late in the spring of 1934, due to the small quantity of available moisture. The rains in June, however, penetrated the soil to a depth of 2 feet and stimulated rapid development. This condition prevailed until early July, when the 
drought became most severe. By the middle of July, all vegetation was badly wilted and many plants were completely dormant. They remained thus until rains late in August and early in September supplied sufficient moisture for growth.

It was during the drought of 1934 that the most exposed locations in this habitat suffered greatly. The bluish-gray color of the short grasses indicated that there were large areas where life was completely extinct. In other places, however, where the normal straw color was retained, the plants proved to be only dormant. It was further observed that areas suffering greatest losses were frequently occupied by a larger percentage of buffalo grass than blue grama grass.

Feeble growth of the two short grasses was observed late in March, 1935, where the layer of accumulated dust did not exceed 1 inch. This meager activity was reduced to almost nil during April when the greatest amount of dusting occurred. The rains of May, however, which were far above normal, washed away the dust and stored enough mo:sture in the soil to stimulate unusual plant activity. The stolons from the remnants of buffalo grass grew very rapidly. Early in June, when growing conditions were optimum, they often increased in length as much as an inch per day. It was not uncommon to find stolons 2 to 12 inches long rooted at the nodes where the cover was sufficiently open to permit them to make contact with the moist soil (Fig. 22). In some

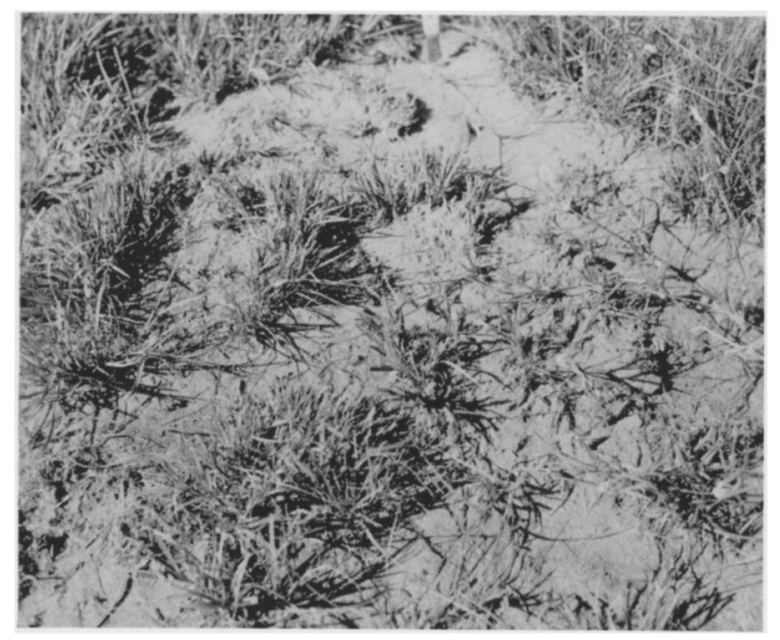

Fig. 22. Photo at Phillipsburg, Kansas, showing open places in the short-grass cover caused by 2 years of drought. These were quickly reclaimed by stolons of buffalo grass in the spring of 1935. Most of the stolons were killed by the drought later in the season.

places, however, stolons were found to have grown one over the other until they had produced a carpet several inches thick. Under such circumstances, rooting at the nodes was impossible. Furthermore, it was frequently found that they grew over the dead remains of other grasses, which likewise prevented root development.

Numerous seedlings of buffalo grass and blue grama grass were scattered through the open places in the vegetation. Seedlings of six-weeks fescue (Festuca octoflora) were also found throughout the short grasses for the first time since 1932. On June 25, a few green sprouts were found growing from the borders of nearly dead bunches of wire grass. Buffalo grass stolons had become so abundant that they formed a heavy mat over much of the soil. By this time, many had reached lengths of 18 to 24 inches. The numerous small bunches of blue grama that survived the drought were now extending their cover by myriads of tillers (Riegel, 1940).

All short grasses, except those in depressions, were badly wilted by the middle of July. Many of the buffalo grass stolons, when shallowly rooted or when not in contact with the soil, had died back to the parent plant. The reactions of the grasses to the environmental conditions to which they were subjected indicated that under extremely adverse conditions the breakdown is rapid. Conversely, when conditions become favorable, replacement is equa'ly rapid.

Growth was renewed during the latter part of Narch, 1936, and continued intermittently through May. The exceptionally dry months of June and July, however, forced all of the vegetation into dormancy and in many instances reduced the cover to nearly zero. In most places, the basal cover reached its minimum for the drought period in 1936, although the rains of August and September were sufficient to stimulate a small amount of fall growth.

The soil was extremely dry in the spring of 1937 and growth was not renewed until late May when the soil was moistened to a depth of 12 inches. This small supply of moisture was soon exhausted, and growth continued only intermittently until the rains of July supplied enough water to initiate the most vigorous growth of the season. By early July, a few dwarfed plants of Festuca octoflora were scattered throughout. The short grasses remained alive during August, but there was no apparent growth except in the more moist buffalo wallows and near the large drought cracks in the soil. The rains of late August provided some soil moisture and the grass which was scattered sparsely over the area produced short flower stalks early in September. Buffalo grass stolons also began growth, but this continued for only a short period.

The rainfall of April and May, 1938, was above normal, but due to excessive runoff only a comparatively small amount was stored in the soil. The short grasses began growth early in April and reached their maximum during late May and early June. By June 6, numerous buffalo-grass stolons, from 3 to 8 inches long, were radiating in all directions from the parent plants. Numerous tillers of blue grama grass were being added to the outside of the small tufts of living plants.

Myriads of buffalo grass and blue grama grass seedlings occupied the open spaces between the bunches of grass. It was not uncommon to find as 
many as 10 to 25 per square foot. Growth continued with no interruption until early in July when the effects of drought became apparent. On July 18 many of the seedlings were dead. The tufts of mature grasses were dormant and many of the stolons of buffalo grass had died back to the place of their origin. The rains of late August and early September stored sufficient moisture in the soil to support the production of flower stalks of blue grama grass. Later study revealed, however, that a comparatively small percentage of caryopses were produced (Savage, 1937).

Early spring growth in 1939 was unusually weak. Light rains during April were insufficient to support active plant growth. During May, which was very dry, the vegetation became practically dormant. Rains in June, however, stimulated considerable activity which lasted until the first week in July, when the grasses again became dormant until the coming of showers in early August. Blue grama was in full head and buffalo-grass stolons were 4 to 8 inches long by the latter part of the month. Production of flower stalks on the blue grama, however, was again of no avail, since practically no caryopses were formed (Fig. 23). Side-oats grama and western wheat grass were commonly found in the buffalo wal-

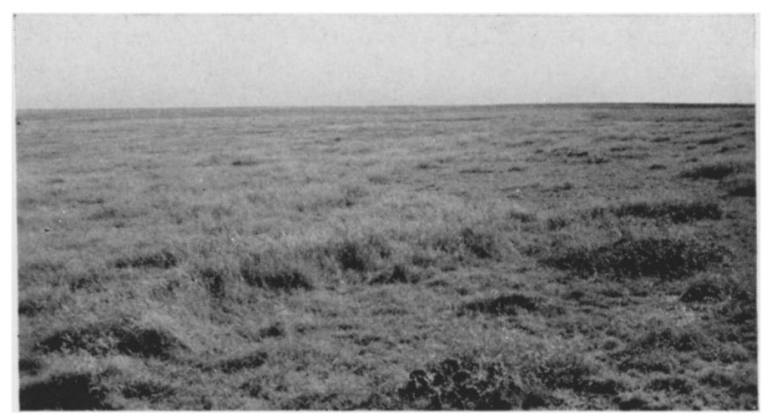

Fig. 23. Production of flower stalks of blue grama grass in the fall of 1939 on a moderately grazed area. Scarcely any of the florets contained caryopses. lows. A few bunches of Aristida longiseta, in full head, were scattered through the disturbed areas on the gentle slopes.

\section{MODERATELY GRAZED BUCHLOE-BOUTELOUA TYPE}

Studies on the changes of the plant population were not limited to ungrazed areas. In the spring of 1935 meter quadrats were staked and charted in representative parts of a moderately grazed area. In October, 1935, the average percentage of basal cover was 49.2 (Table 12). This amount had been reduced

TABLE 12. Change in percentage of basal cover in 10 meter quadrats in a moderately grazed Buchloe-Bouteloua type at Hays, Kansas.

\begin{tabular}{r|r|r|r|r|r}
\hline \hline Species & 1935 & 1936 & 1937 & 1938 & 1939 \\
\hline Bouteloua gracilis............ & 49.1 & 3.9 & 7.0 & 15.9 & 14.4 \\
Buchloe dactyloides.......... & 4 & 1.7 & 4.6 & 12.3 \\
Sporobolus cryptandrus........ & .1 & .3 & .2 & 1.8 & 1.1 \\
\hline Total ............... & 49.2 & 4.6 & 8.9 & 22.3 & 27.8 \\
\hline
\end{tabular}

to 4.6 percent by the autumn of 1936 , after which there were good gains through the 3 succeeding years. The total of 27.8 percent cover in 1939 was approximately 5 percent greater than that on the ungrazed area. This was due to an unusual increase in the cover of buffalo grass between 1938 and 1939 . In some locations, however, the increase in cover of blue grama accounted for most of the gain between 1938 and 1939 (Fig. 24). The relative abundance of buffalo grass and blue grama grass was not determined separately until after 1935 . Buffalo grass was reduced to its minimum of 0.4 percent in 1936. The more drought resistant blue grama grass fared somewhat better and had a cover of 3.9 percent. The response of the two grasses to drought was similar in other locations, buffalo grass suffering the greater loss and often almost disappearing except in buffalo wallows (Fig. 25). Upon the advent of better growing conditions, however, recovery was also much more
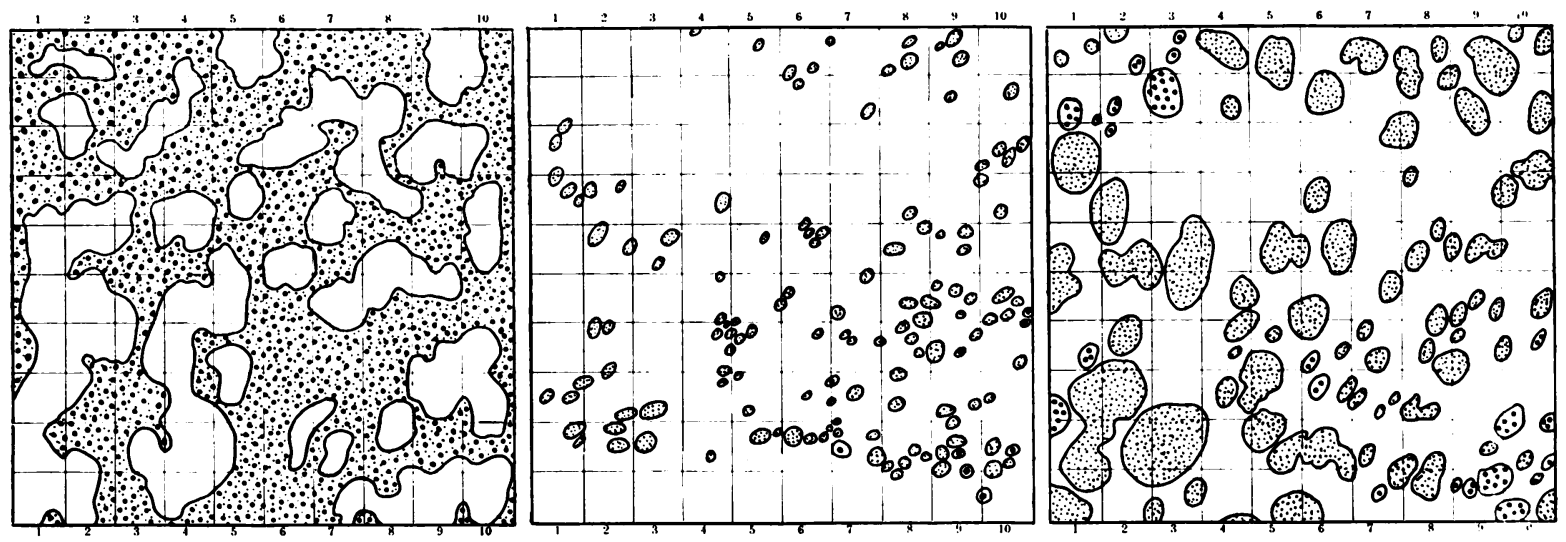

Fig. 24. Quadrat on moderately grazed short-grass type with dense cover. Cover of short grasses in the fall of 1935 (left) was 72.4 percent. A minimum cover of 0.15 percent of buffalo grass (large dots) and 2.8 percent of blue grama (small dots) was reached by 1937 (center). Significant gains were made by these grasses during 1938 and 1939 and, when charted in the fall of 1939 (right), buffalo grass had a cover of 3.1 percent and blue grama grass 24.2 percent. 


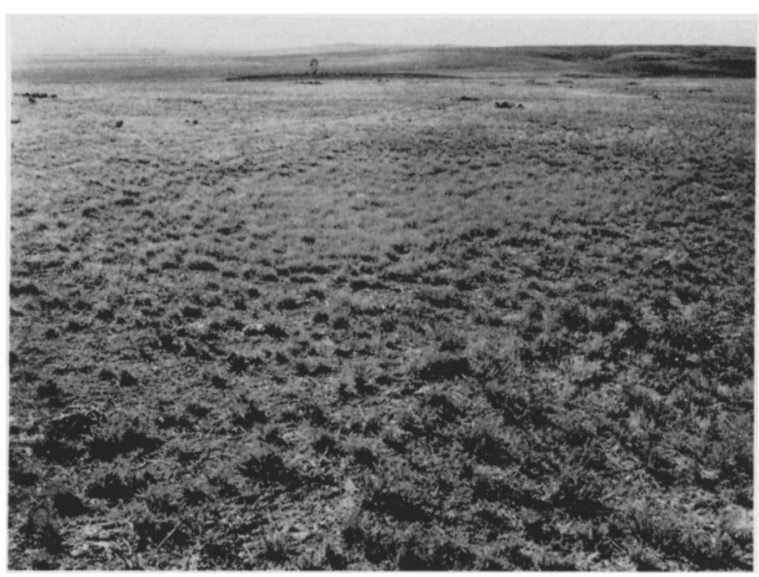

Fig. 25. Short-grass cover at Hays, Kansas, late in August, 1937. Nearly all of the vegetation is blue grama grass, except that in the depression (center) where buffalo grass is abundant.

rapid; in fact, it was not uncommon for this species to increase its area from 3 to 10 times the original in a single season under optimum growing conditions.

Broken cover permitted the invasion of $S$ porobolus cryptandrus, which was present in only a small amount in 1935. The increase was not great but definite gains were made after 1937. The results of these studies indicate that moderate grazing is no great handicap to the normal development of the short grasses; in fact, there is reason to believe that moderate grazing under normal precipitation will produce a more uniform cover than that developed under total protection (Savage, 1939).

\section{OVERGRAZED BUCHLOE-BOUTELOUA TYPE}

Studies of an overgrazed short-grass type were made concurrently with those of one moderately grazed. In the fall of 1935 the basal cover on this type (22.1 percent) was less than half of that on the moderately grazed area (Table 13). The loss of both short grasses was extreme during the following year, the cover being only 2.6 percent in the fall of 1936 .
TABIE 13. Change in percentage of basal cover in 7 meter quadrats in an overgrazed Buchloe-Bouteloua type at Hays, Kansas.

\begin{tabular}{|c|c|c|c|c|c|}
\hline Species & 1935 & 1936 & 1937 & 1938 & 1939 \\
\hline Bouteloua gracilis. & 9.1 & 1.9 & 4.9 & 7.0 & 10.0 \\
\hline Buchloe dactyloides. & 12.0 & .5 & 1.8 & 5.0 & 8.3 \\
\hline Bouteloua curtipendula. & .4 & .1 & .1 & .4 & .4 \\
\hline Triodia pilosa........ & .2 & .1 & .4 & .5 & .4 \\
\hline Sporobolus cryptandrus. & & 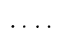 & .1 & .4 & .3 \\
\hline Andropogon furcatus.... & .4 & $\ldots$ & $\ldots$ & $\ldots$ & $\ldots$ \\
\hline Total. & 22.1 & 2.6 & 7.3 & 13.3 & 19.4 \\
\hline
\end{tabular}

Areas 10 to 15 feet in diameter and containing nothing but a few scattered annual weeds were frequently found.

The cover was increased to 7.3 percent in 1937; to 13.3 percent in 1938 ; and further increased to 19.4 percent in 1939 (Fig. 26).

A few scattered plants of Bouteloua curtipendula, Triodia pilosa, and Sporobolus cryptandrus were found in some of the quadrats studied. Andropogon furcatus was present in a very small amount during 1935 in one quadrat where conditions were slightly more mesic than average. The intensity of grazing was materially reduced on these areas during 1930 and 1939; hence, recovery was more rapid than in they had been continuously overgrazed. The effect: of overgrazing and constant dusting on the shor grasses were little short of tragic. The cover wa: often reduced to less than 1 percent and growth was extremely weak (Fig. 27).

A comparison of the relative effects of the drought upon the Buchloe-Bouteloua type when subjected to different conditions is shown in Figure 28. The average basal cover on the area ungrazed since 1932 was better than that of the moderately grazed one, except in 1939. The cover in the overgrazed area was correspondingly lower than that of the moderately grazed one. Studies made in the spring of 1940 showed that the autumn and winter losses on the overgrazed areas far exceeded those of pastures that were moderately grazed or ungrazed. Data obtained
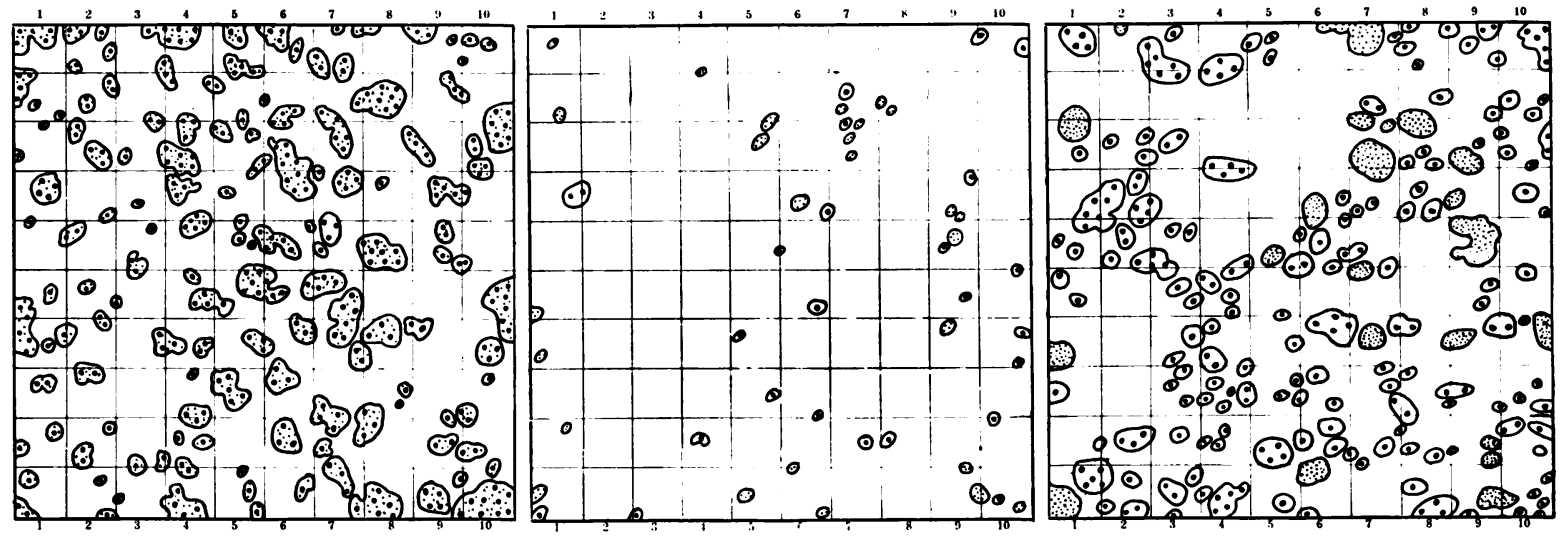

FIG. 26. Quadrat in typical overgrazed area of closed-type short grass. The buffalo grass (large dots) and blue grama (small dots) were not charted separately in 1935 (left), when the cover of the two grasses was 19.8 percent. The minimum of 0.84 percent was reached in 1936 (center). Note the rather uniform distribution of the surviving clumps throughout the quadrat. The basal cover increased to nearly 19.0 percent in 1939 (right). 


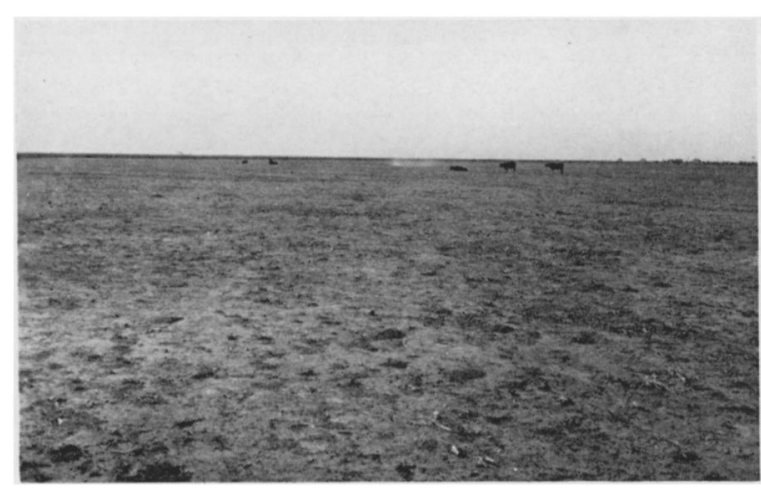

FIG. 27. Range where grazing and continuous dusting has destroyed nearly the entire cover. Only a few seattered bunches, half covered with dust, remain. Hays, Kansas, 1939.

from several areas revealed that often as much as 75 percent of the 1939 cover had perished by the middle of May, 1940 ( $c f$. Weaver and Albertson, 1940).

\section{Studies in the Ecotone}

Studies on the change of vegetation were not limited to those of the typical little-bluestem and shortgrass types, but extended through the transition belt which lies between these two habitats. Investigations were begun in the fall of 1932 , and changes that have occurred subsequently have been closely followed. In places the transition from short grass to little bluestem was so abrupt as to make it possible to locate a meter quadrat so that it included a part of each type. Elsewhere, the little bluestem was scattered widely in bunches among the short grasses.

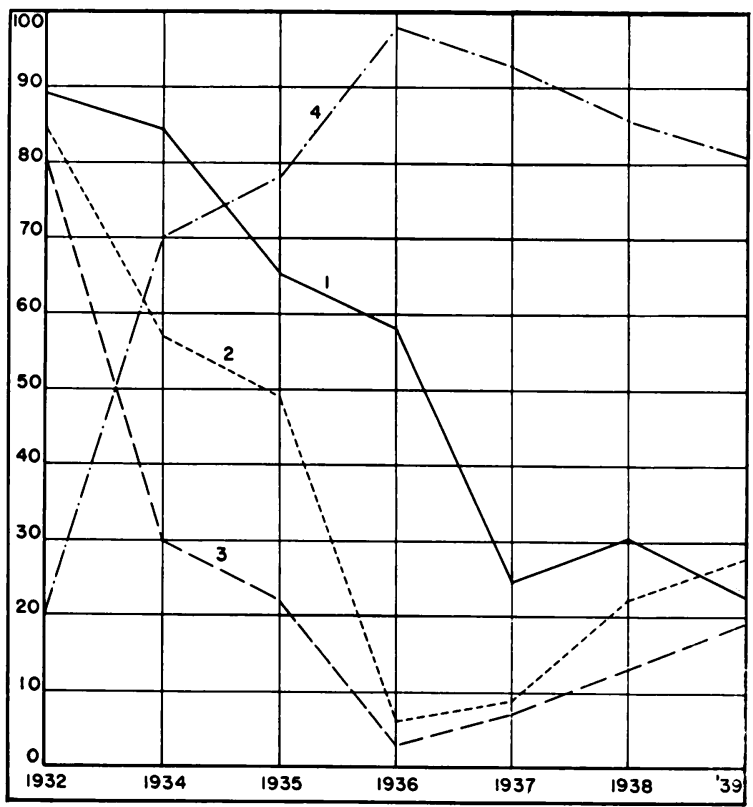

Fig. 28. Decrease in percentage of basal cover in a short-grass type: (1) ungrazed, (2) moderately grazed, and (3) overgrazed. The percentage of bare ground in the overgrazed range (4) reached its maximum in 1936.
LITTLE BLUESTEM-SHORT GRASS MIXTURE

In the fall of 1932, the average basal cover in quadrats located where there was a relatively large amount of little bluestem was 65.3 percent (Table

TABLE 14. Change in percentage of basal cover in 10 meter quadrats in an ungrazed area on the ecotone between the short grasses and little bluestem at Hays, Kansas.

A. Large amount of little bluestem.

\begin{tabular}{|c|c|c|c|c|c|c|c|}
\hline Species & 1932 & 1934 & 1935 & 1936 & 1937 & 1938 & 1939 \\
\hline Bouteloua gracilis & 207 & 350 & & 18.7 & 26.9 & $: 0.0$ & 35.7 \\
\hline Buchloe dactyloides. & 20.7 & 30.9 & 42.8 & 1.6 & 4.2 & 9.5 & 12.2 \\
\hline Andropogon scoparius. & 40.1 & 10.1 & 5.7 & $1 . t$ & .2 & $\cdots$ & $\cdot$ \\
\hline Andropogon furcatus & 4.5 & .8 & $\varepsilon$ &.$\varepsilon$ & .4 & .1 & .2 \\
\hline Bou'eloua curtipendula & $\ldots$ & 2.5 & 4.9 & $2 . \dot{0}$ & 2.3 & 2.4 & 3.2 \\
\hline Total & 65.3 & 49.3 & 54.2 & 24.7 & 34.0 & $41 . \varepsilon$ & 51.3 \\
\hline
\end{tabular}

B. Small amount of little bluestem.

\begin{tabular}{|c|c|c|c|c|c|c|c|}
\hline Species & 1932 & $19 \cup 4$ & $19 \div 5$ & 1936 & 1937 & 1938 & 1939 \\
\hline Bouteloua gracilis. & $76 ?$ & & & & 21.5 & $21 . \mathrm{g}$ & 29.2 \\
\hline Buchloe dactyloides. & 10.2 & 14.0 & 08.5 & 50.8 & 11.7 & 15.2 & 19.3 \\
\hline Andropogon scoparius. & 7.2 & 2.1 & .9 & .2 & & & . \\
\hline Andropogon furcatus & .. & .1 & .1 & .0 & & & \\
\hline Bouteloua curtipendula & . & .3 & .0 & $\therefore$ & .4 & .2 & .0 \\
\hline Total & 83.4 & $76 . \dot{2}$ & 69.5 & 50.8 & 33.4 & 37.3 & 48.5 \\
\hline
\end{tabular}

14A). Of this, 20.7 percent was buffalo grass and blue grama grass, and the remainder was big and little bluestem. The total cover was reduced to 49.3 percent by the fall of 1934, but had increased to 54.2 percent when charted in the fall of 1935. The most destructive effects of the drought occurred in 1936; the basal cover was then reduced to only 24.7 percent. Considerable increase occurred in 1937 and still more in 1938, and even the exceptionally dry vear of 1939 produced a further increase, when the cover reached 51.3 percent (Fig. 29).

It is of interest that the chief dominant, little bluestem, which had a cover of 40.1 percent in 1932, rapidly descreased to 0.2 percent in 1937 and then disappeared. Big bluestem furnished 4.5 percent cover in 1932, but although it suffered considerable loss, very small amounts were found continuously throughout the 7 years. It was the increase in short grasses that prevented almost complete destruction of vegetation. In 1934, the cover of buffalo grass and blue grama grass had increased from 20.7 percent to 35.9 percent. A further increase to 42.8 percent occurred by the fall of 1935 . This increase was caused by migration of the short grasses into the portions of the quadrats previously occupied by the bluestems and not by an actual inerease in density in the parts which they originally covered.

The short grasses had spread throughout the quadrats by 1936 , but the intense drought had reduced the cover of vegetation in a manner similar to that in other locations occupied by these species. It was this thinning out process that caused such an abrupt loss between 1935 and 1936. The increase from 24.7 per- 

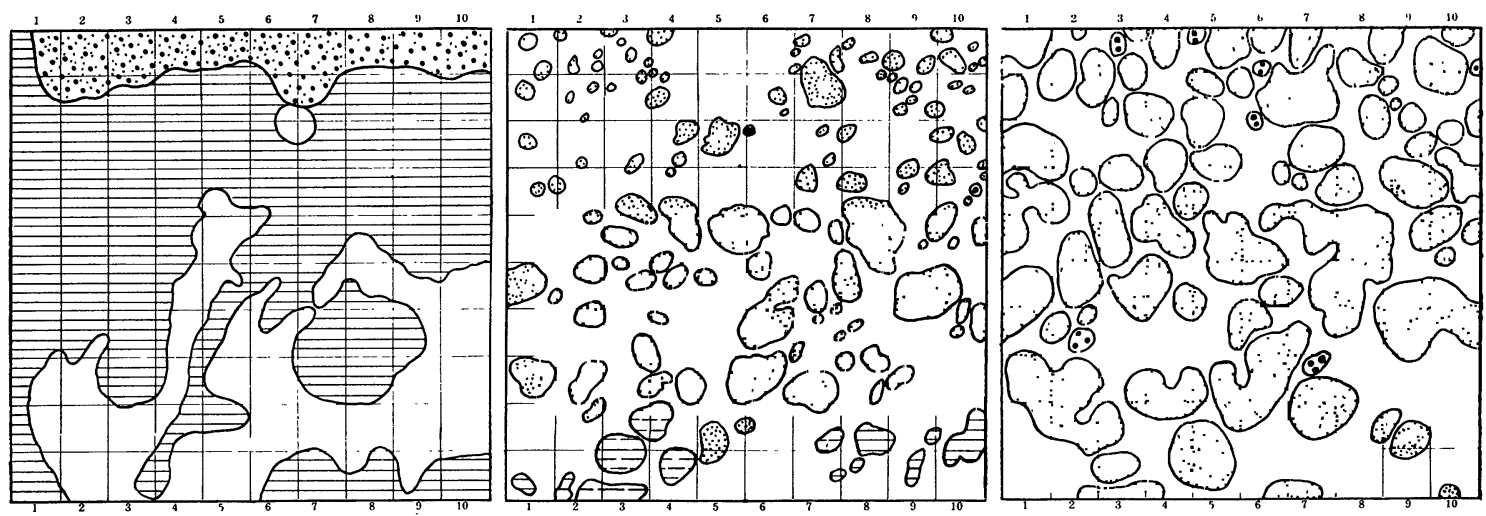

Fig. 29. Quadrat typical of the ecotone between short grasses and little bluestem. The short grasses (dots) formed a dense cover over one side of the area in 1932 (left). The remainder was occupied by little bluestem (horizontal hatch). The open space is bare ground. As the drought continued, little bluestem was all killed and replaced by short grasses and side-oats grama (broken horizontal hatch). The cover was reduced from 71 percent in 1932 to 19 percent in 1936 (center). By 1939 (right) it had increased to 51 percent, due primarily to an excellent growth of blue grama grass.

cent of basal cover in 1936 to 51.3 percent in 1939 was made possible by the gradual spread of both short grasses. Blue grama grass nearly doubled its cover, and buffalo grass, which was reduced to 1.6 percent in 1936, increased its holdings to 12.2 percent-more than seven times its minimum. Side-oats grama, which was absent in 1932, afforded 2.5 percent of the cover in 1934. No large gains of this grass occurred, but its persistence indicates a greater drought resistance than that of the two bluestems.

In areas where little bluestem constituted a small percentage of the vegetation in 1932 (Table 14B), the change in cover was considerably different from that in the more mesic locations where the little bluestem was relatively heavy. The average total cover in the fall of 1932 was 83.4 percent. The decrease was gradual thereafter until 1937, when the minimum of 33.4 was reached. By the fall of 1938 it had inereased to 37.3 percent, and to 48.5 percent in 1939 . Since little bluestem formed only a small percentage of the vegetation in the beginning, the total cover was not changed appreciably by its replacement with the more xeric short grasses.

The short grasses covered 76.2 percent of the area charted in 1932. They lost slightly in 1934, and a little more in 1935 when the cover was reduced to 68.5 percent. The extreme drought of 1936 reduced the basal area of short grasses to 50.3 percent, and further reduction occurred in 1937 when it reached its minimum of 33.0 percent. Each of the short grasses made gains thereafter. Both bluestems disappeared in 1936. Side-oats grama, which appeared first in 1934, was never present in any considerable amounts.

SIDE-OATS GRAMA-SHORT GRASS MIXTURE

Side-oats grama had evidently invaded the short grasses during the wet period previous to the drought. It constituted the major portion of the vegetation in local areas on the more xeric side of the ecotone between the little-bluestem and the shortgrass habitats. Several permanent quadrats representative of this condition were charted in the fall of 1932 (Table 15). The total cover was 81.8 per-

TABLE 15. Change in percentage of basal cover in an ungrazed area occupied by side-oats grama and short grasses in 1932 at Hays, Kansas.

\begin{tabular}{|c|c|c|c|c|c|c|c|}
\hline Speci s & 1932 & 1934 & 1935 & 1936 & 1937 & 1938 & $19 £ 9$ \\
\hline Bouteloua curtix endula & 60.2 & $50 . t$ & 21.7 & $3 . \varepsilon$ & 5.9 & 2.7 & 4.3 \\
\hline Bouteloua gracilis..... & $21 f$ & 240 & 260 & 5.7 & 15.9 & 15.0 & 19.0 \\
\hline Buchloe dactyloides..... & $21 . \mathrm{C}$ & 24.0 & 20.0 & $4 . \varepsilon$ & 11.9 & 17.4 & 205 \\
\hline Andropogon furcatus.... & & & & .1 & .3 & .2 & .1 \\
\hline Aristida purpurea. . & . & .2 & $\therefore$ & & & & \\
\hline Sporobolus cryptandrus... & & & . & .1 & .7 & .9 & 1.0 \\
\hline Tote & 81.8 & 74.7 & 47.8 & 14.0 & 34.7 & 36.2 & 44.9 \\
\hline
\end{tabular}

cent. This amount was diminished to 74.7 percent in 1934 and to 47.9 percent in 1935 . The minimum of 14 percent was reached in 1936 . The gain in cover thereafter was relatively rapid and by 1939 it was 44.9 percent.

The behavior of side-oats grama in this location was similar to that of the little bluestem farther down the slope. This grama grass, with a cover of 60.2 percent in 1932, rapidly decreased to only 3.3 percent in 1936. It gained slightly in 1937, but reached its minimum of 2.7 percent in 1938 , and then increased to 4.3 percent in 1939 .

The short grasses, which had 21.6 percent cover in 1932, increased to 26 percent in 1935. This cover was reduced to only 10.5 percent in 1936 . The gains were constant thereafter and by the fall of 1939 these two grasses occupied nearly 40 percent of the area.

MIXED MID GRASSES AND SHORT GRASSES

In 1934 it was observed that the more mesic grasses, such as little bluestem and wire grasses that were scattered through the short grasses on the nearly level tablelands, had suffered exceptionally 
heavy losses. Permanent quadrats were located and charted to show the cover in 1934 after 2 years of extreme drought. The average cover where little bluestem was the dominant mid grass was 33.6 percent (Table 16A). The cover was reduced to 21.8

TABLE 16. Change in percentage of basal cover in a moderately grazed area occupied (A) by little bluestem and short grasses, and (B) by wire grass and short grasses at Hays, Kansas.

A

\begin{tabular}{|c|c|c|c|c|c|c|}
\hline Species & 1934 & 1935 & 1936 & 1937 & 1938 & 1939 \\
\hline Andropogon scoparius & 19.0 & .5 & & & & \\
\hline Bouteloua curtipendula... & 7.2 & $\ldots \ldots$ & & & . & $\ldots \ldots$ \\
\hline Bouteloua gracilis. & 4.3 & 13.0 & 8.0 & 18.4 & 26.0 & 30.3 \\
\hline Buchloe dactyloides & 1.4 & 5.2 & 1.0 & 4.4 & 8.5 & 4.9 \\
\hline Aristida purpurea.. & 1.7 & 3.1 & .5 & $\cdots \cdots$ & $\cdots$ & $\cdots \cdots$ \\
\hline Total. & 33.6 & 21.8 & 9.5 & 22.8 & 34.5 & 35.2 \\
\hline
\end{tabular}

B

\begin{tabular}{|c|c|c|c|c|c|c|}
\hline $\left.\begin{array}{l}\text { Bouteloua gracilis....... } \\
\text { Buchloe dactyloides..... }\end{array}\right\}$ & 24.4 & 25.9 & $\begin{array}{l}4.6 \\
1.5\end{array}$ & $\begin{array}{r}14.3 \\
5.4\end{array}$ & $\begin{array}{l}18.6 \\
13.5\end{array}$ & $\begin{array}{r}19.7 \\
6.9\end{array}$ \\
\hline Aristida purpure & 7.8 & 1.4 & .1 & $\theta$ & $\cdots$ & \\
\hline & & & 6.2 & 9.7 & 2. & \\
\hline
\end{tabular}

percent in 1935 and to only 9.5 percent in 1936 . A gradual increase occurred during the next 3 years, and a total of 35.2 percent was present in 1939. The 19 percent of little bluestem in 1934 had decreased to 0.5 percent in 1935 and was absent thereafter. Sideoats grama suffered a similar fate. The two short grasses had a cover of less than 6 percent in 1934 . They increased to slightly over 18 percent in 1935 , but were reduced to 9 percent in 1936. Basal cover of blue grama grass changed from 8 percent in 1936 to 30.3 percent in 1939 . Buffalo grass likewise increased from 1 percent to 4.9 percent during the same period.

The two wire grasses (Aristida purpurea and $A$. longiseta) were commonly found in local weedy areas on gentle slopes in 1934, when studies concerning the behavior of these grasses were begun (Table 16B). The first year the total cover was 32.3 percent, 7.8 percent of which was wire grass and the remainder, 24.4 percent, short grasses. The cover of wire grass rapidly decreased and by 1936 only remnants remained. Observations in areas adjacent to those of intensive study indicated that this grass was reduced to less than 1 percent throughout the area. A few scattered plants were found growing in local weedy places in 1938; although none were present in the quadrats that were charted.

\section{Changes in the Andropogon furcatus Type}

Great changes also occurred in the big bluestem type which characterized the larger ravines and most mesic slopes. At the beginning of drought in 1933 big bluestem constituted about 75 percent of the vegetation. Species of less importance included Bouteloua curtipendula, wild rye grass (Elymus virginicus) and long-leaved dropseed (Sporobolus asper hookeri).
Decrease in available soil moisture in this habitat lagged behind that of the little-bluestem and shortgrass types; hence, the changes in the composition and abundance of the vegetation were slower to appear. The change, at first, was one of shifting in the relative amount of the various native grasses rather than an actual decrease in the total cover. Isater, however, as the available soil moisture decreased and as the amount of loose soil washed in from the partly bared watersheds increased, the plant population was materially reduced. All of the more mesic grasses decreased both in size and abundance. These included big bluestem, tall panic grass (Panicum virgatum), Indian grass (Sorghastrum nutans), wild rye grass (Elymus virginicus), and plains bluegrass (Poa arida). The more xerie grasses, however, such as western wheat grass, side-oats grama, and long-leaved dropseed, made definite gains. Western wheat grass, a species immediately bordering the ravines, invaded the lowlands from this vantage point, and long-leaved dropseed spread from small areas of nearly pure stands in the heads of ravines.

Debris of soil and dead plants washed down from above and often covered much of the vegetation, thus ereating bare areas. These were usually populated by myriads of such weedy annuals as the common sunflower (Helianthus annuus), lamb's quarters (mostly Chenopodium album), and Russian thistle (Salsola pestifer). While none of the species entirely disappeared, a loss of fully 25 percent of the vegetation resulted from the combined influences of drought and consequent soil erosion and deposit.

\section{Studies in Southwestern Kansas}

Studies of the effects of the drought on the vegetation were considerably expanded in 1937 by placing meter quadrats in representative areas at 15 different stations in southwestern Kansas (Fig. 1). Each quadrat was recharted in 1938 and again in 1939 , and studies were made as to the general condition of the surrounding vegetation. The results are grouped according to the conditions to which the area was subjected at the time of the initial quadratting. The amount of subsequent dusting has varied somewhat, but the classification is reasonably accurate. Condition 1 indicates light dusting and moderate grazing; 2, light dusting and overgrazing; 3 , heavy dusting and moderate grazing; and 4, heavy dusting and overgrazing (Table 17).

The basal cover in 1937 varied from 10.0 to 32.9 percent under condition 1 and averaged 19.8 percent. The average was increased to 27.8 in 1938 , a gain which was again lost during the drought of 1939 (Fig. 30). The relative proportion of buffalo grass and blue grama varied considerably and generally no apparent reason could be found for the differences. At three of the four stations, the percentage of buffalo grass cover averaged much higher than that of blue grama grass. At Scott City, the reverse was true. At Oakley, there was a large gain in buffalo grass between 1937 and 1938 and then an enor- 
TABLE 17. Deviation from mean precipitation, condition, percent of basal cover of blue grama grass and buffalo grass, and basal cover on representative pastures near each station.

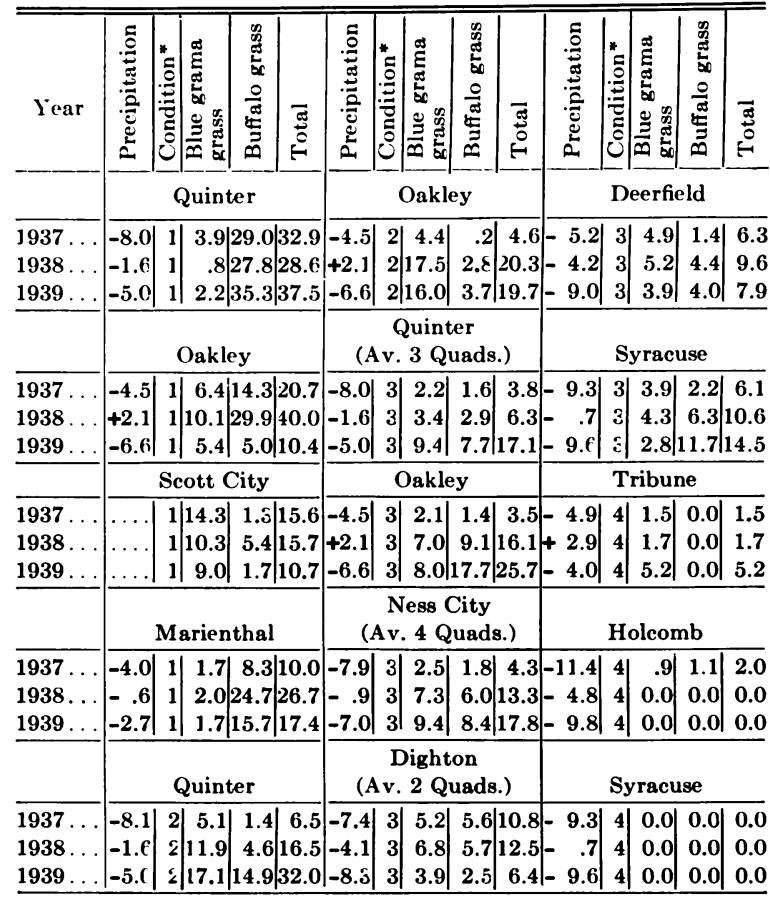

*Condition at time quadrats were laid out in 1937: 1, lightly dusted, moderately grazed; 2 , lightly dusted, overgrazed; 3 , heavily dusted, moderately grazed; and 4, heavily dusted, overgrazed.

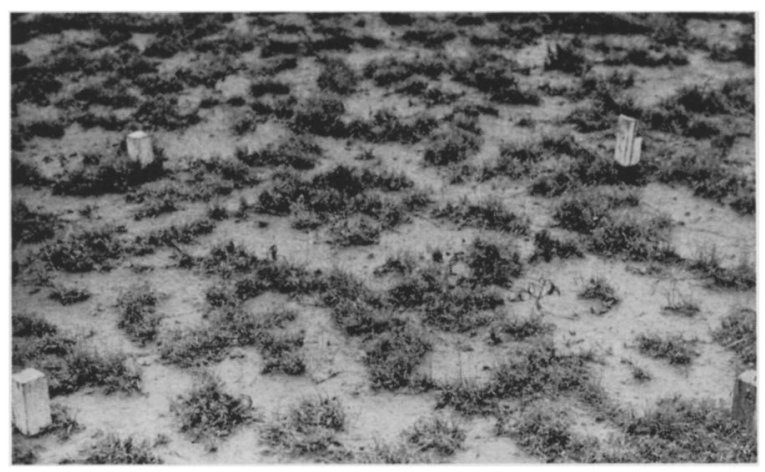

Fig. 30. Meter quadrat in a lightly dusted and moderately grazed short-grass pasture near Marienthal, Kansas. The total cover in August, 1939, when the photograph was taken, was 17.4 percent.

mous loss in 1939. The rainfall deficit for 1939 at Oakley was 6.6 inches, but it was 2.1 inches above normal in 1938. This readily explains the loss that occurred between 1938 and 1939. At Quinter, there was a gain between 1938 and 1939 in spite of a greater rainfall deficit during the latter year (Fig. 31). It seems that the ability of buffalo grass to endure dry periods depends upon the depth to which the roots arising from the stolons have penetrated when drought begins.

Under light dusting and overgrazing (condition 2), the average cover was 5.5 percent in 1937 . This was

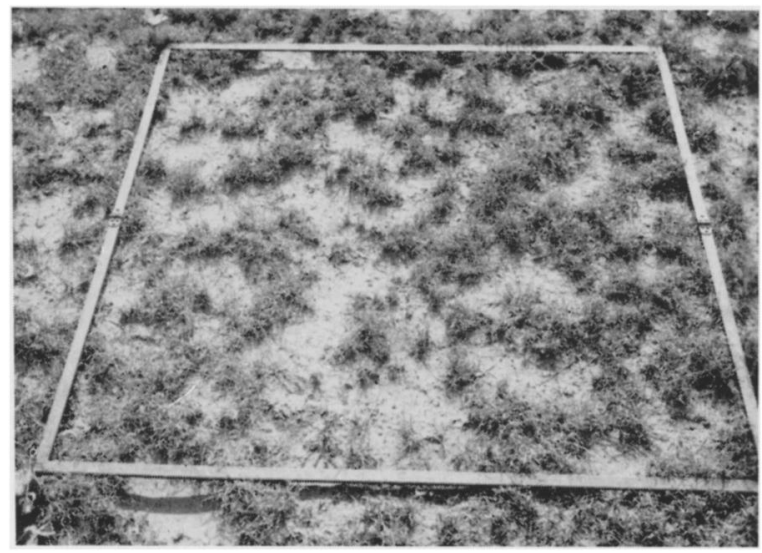

Fig. 31. Meter quadrat in a lightly dusted and moderately grazed short-grass pasture near Quinter, Kansas. The cover in 1939 was 37.5 percent. Photo in September, 1939.

increased to 18.4 percent in 1938 and to 25.9 percent in 1939. Oakley had a cover of 19.7 percent and Quinter, 32.0 percent in 1939 (Fig. 32). The relatively large cover at Quinter in 1939 resulted from a great increase in the cover of buffalo grass.

When the area was heavily dusted and moderately grazed (condition 3 ), the average percentage of basal cover was 5.8 in 1937. It increased to 11.4 percent in 1938 and then to 14.9 percent in 1939 (Fig. 33). Cover was shared about equally by the two short grasses except at Oakley, where the buffalo grass had a cover of 17.7 percent in 1939, as compared with 8 percent for blue grama.

Vegetation under condition 4, where the grass was heavily dusted and overgrazed, suffered greatest from the drought. The average cover in 1937 was 1.2 percent. In 1938 it was reduced to 0.6 percent, and in 1939 , it had increased to only 1.7 percent. Several of these areas contained no vegetation at all except an occasional forb or ruderal. The cover of vast areas of native prairie, because of severe dusting and

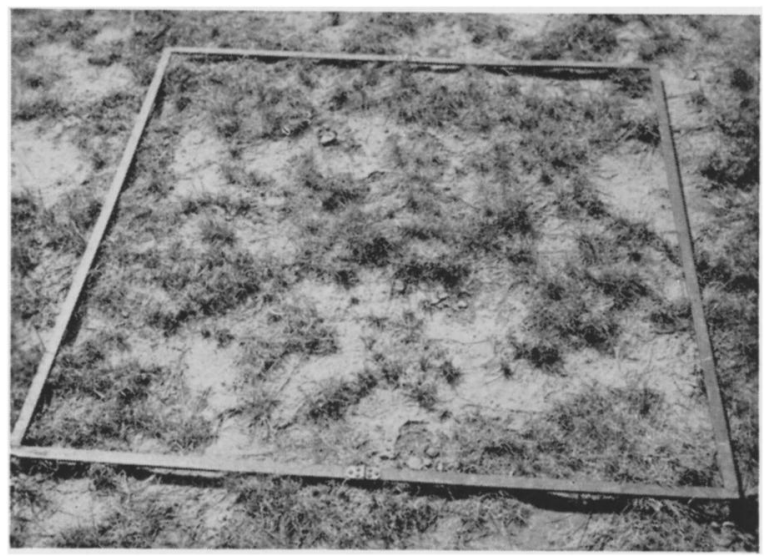

Fig. 32. Meter quadrat in a lightly dusted and overgrazed pasture near Quinter, Kansas. The basal eover in 1939 was 32 percent. Photo, Sept. 5, 1939. 


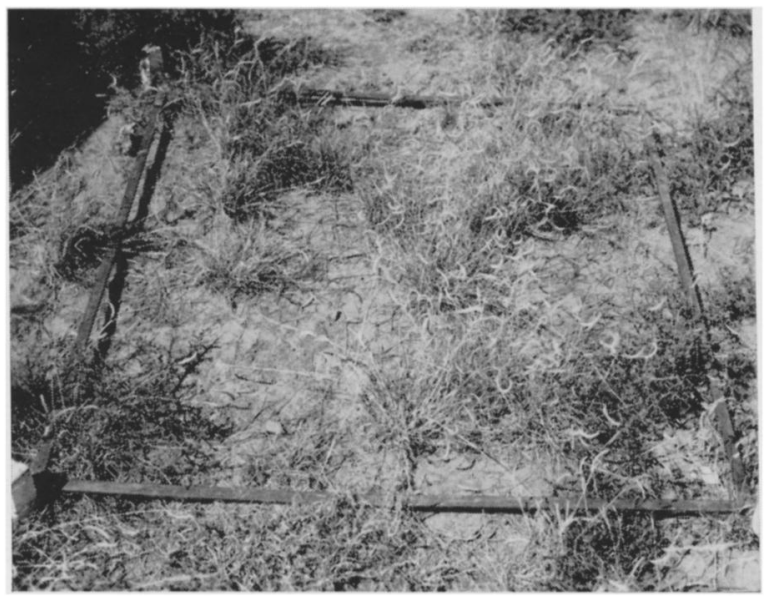

Fig. 33. Meter quadrat in a heavily dusted and moderately grazed pasture near Quinter, Kansas. The cover in the autumn of 1939 was 15.7 percent. Photo, Sept. 5, 1939 .

overgrazing, has been reduced to nearly zero (Fig. $34)$. This type of prairie constitutes a large portion of the grassland near the center of the dust bowl. Farmers report that many of the dust storms since 1935 have arisen in these prairies. Drifts of soil, often 30 inches high and extending for many rods, are frequently found in this region.

The yield of palatable forage in overgrazed pastures is less than 10 percent of that produced in well-managed ones. This fact is exceedingly important when considering the rate of stocking the range. Many ranges originally stocked at the rate of one animal unit to 10 to 12 acres now require 30 to 50 acres to support one animal. This endition has placed an exceedingly d'fficult task upon ranchers since it has often been practically impossible to produce supplementary feeds such as sorghums. As a consequence, they have been compelled to dispose of most of their livestock, thereby greatly reducing the farm income and making the earning of an independent living almost impossible. It seems clear that

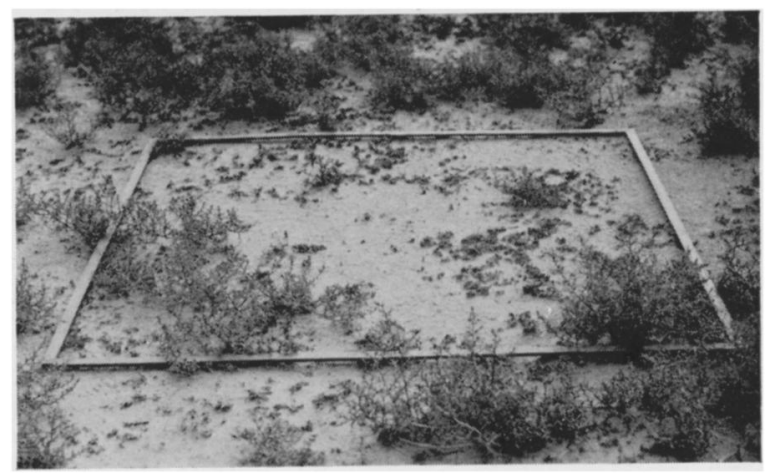

Fig. 34. Meter quadrat in a heavily dusted and overgrazed pasture near Holcomb, Kansas. Only the dead crowns of the native grasses remain to distinguish it from the adjacent cultivated fields. Most of the weeds are Salsola pestifer. Photo, July 27, 1939. several years of normal or above normal precipitation with the most judicious range management will be necessary to restore the former cover of grasses.

\section{SLMMARY}

The prairie vegetation of western Kansas has been studied through 7 years of continuous drought, 1933 to 1939 , inclusive. Investigations were centered at Hays, but studies were made in many count:es. Water content of soil has been determined weekly during the growing season, and a record of aerial environmental factors obtained. Reactions of the mixed prairie and short grass vegetation have been recorded year by year in scores of permanent, widely distributed quadrats, and by extensive field notes.

The pioneers found a dense cover of vegetation. They broke only enough sod to grow erops for food, and winter forage and grain for their livestock. Farming, which for a long time was incidental to stock raising, received a great impetus with the invention of labor-saving machinery and a period of high prices for wheat. Despite this stimulus to agriculture, over one third of the land remains unbroken. Saturation of the wheat market turned attention to livestock production just at a time when the range was severely depleted by drought and dust coverage. Extent of grassland was limited and overgrazing and deterioration inevitable.

Moderately grazed and ungrazed prairies were in excellent condition in 1933 because of a very favorable six-year period just preceding when the average annual precipitation (27.8 in.) was approximately 5 inches above normal.

Annual precipitation during each of the drought years was below normal and during 4 of the 7 years nearly 7 inches below. Most of this deficit occurred during the growing season. Periods of 5 to 7 weeks in summer with praetically no rainfall occurred. An accumulated deficit of 6.7 inches in 1933 increased to 21.6 in 1936 and to 34.5 inches in 1939 .

Temperatures were abnormally high dur:ng the drought and duration of periods with high temperatures unusually long. Average daily maximum temperatures for June, July, and August of the 4 driest vears were $93.2^{\circ}, 100.6^{\circ}$, and $94.8^{\circ} \mathrm{F}$., respectively, or $8.0^{\circ}, 7.5^{\circ}$, and $4.4^{\circ}$ higher than for the same months during 1925-1932.

Wind movement was abnormally high. That of 1934 was greatest, being 41,782 miles from April to September, inclusive. The lowest (1936) was 33,838 miles. The highest wind movement occurred in April and May and often resulted in great dust storms. Combined effects of cultivation, overgrazing, and drought created conditions extremely conducive to dust storms. Such storms were frequent but not severe during 1932. Many dust storms of wide extent occurred in April, 1933, but the blowing of dust reached a climax in March and April of 1935. Sometimes the storms were of several days duration. Vast areas of vegetation were smothered by thin blankets of silt or by great drifts of loose earth. After the 
vegetation died, the dust was again moved by the wind and thus supplied the silt for later black blizzards.

The average seasonal evaporation (April to September, inclusive) from a free water surface was 48.5 inches preceding the drought. It was always greater during the drought and was 66.4 inches in 1934. Average monthly evaporation for the drought years was 1.8 inches higher than normal in June, 2.7 inches in July and 1.7 inches in August, and was 8.5 inches above normal for the growing season.

Water content of soil was determined at weekly intervals throughout the growing season to a depth of 5 feet. Available water was the limiting factor to plant production. There was about 2 percent residual water available to plants at certain depths below 2 feet in 1933 but none thereafter. Water was nonavailable in the second foot after the first week in June, 1933, and continuously so except for 2 weeks in June, 1934, and during the entire month in 1935. From 1937 to 1939, inclusive, the second foot of soil had no water available for plant growth. Even water in the surface foot was depleted to an amount nonavailable for growth during three 2-week periods in 1933 , one 4-week period in 1934, and one 7 -week interval in 1935. This occurred when water was also nonavailable at any depth to 5 feet, and the plants succumbed or became dormant. During 3 separate weeks in 1937 they were without available water; similar periods of 2 and 5 weeks duration occurred in 1938, and in 1939 there were three, including one of 4 weeks duration in July and August.

Three types of vegetation, with varying degrees of intermixtures, are common in the mixed prairie of west-central Kansas. They are the little bluestem (Andropogon scoparius) type, common on hillsides and in shallow ravines; the short-grass (BuchloeBouteloua) type, widely distributed over nearly level uplands; and the big bluestem (Andropogon furcatus) type of larger ravines and lower moist slopes.

During the 7 years of drought, vegetation remained wilted or dried over periods of several weeks duration. Periods of dormancy alternated with those of growth several times during a single summer. Many mesic plants disappeared completely and even the most xeric species were reduced greatly in numbers. Animal life was also greatly depleted.

The complete story of the deterioration of the little bluestem type has been recorded. The original basal cover of about 60 percent was composed of approximately one-sixth big bluestem and nearly all of the remainder was little bluestem. Even where protected from grazing, little bluestem decreased so rapidly that only 10 to 20 percent remained in 1935 , and 1 to 4 percent in 1939. Big bluestem was reduced to 2 percent or less. Invasion of more xeric species, especially side-oats grama (Bouteloua curtipendula) and blue grama ( $B$. gracilis) resulted in the minimum basal cover of 16 percent (1936) being increased to 22 to 30 percent in 1939. Accumulated benefits derived from the best drought years were often ex- pressed by better growth the following season, even if dry. Myriads of seedlings sometimes appeared in the open spaces between the living bunches but nearly all succumbed. Opportune showers permitted flowering of mature plants but few viable seeds were produced.

Late in the drought period, large areas of level prairies were found to be completely devoid of little bluestem. Some big bluestem survived owing not only to its greater depth of root system but also to the large amounts of reserve foods in erowns and rhizomes. Side-oats grama, once established in the bared areas, spread considerably, mostly by short rhizomes, the young shoots from them surviving more severe drought than the seedlings. Plants of blue grama grass increased by tillering. The increase was slow but constant in the little bluestem habitat.

In the ungrazed open type, the predrought basal cover was often only 25 percent, and consisted of nearly pure little bluestem. It was reduced rapidly after 1934, and to 12 percent in 1936. Increase of side-oats grama, which became dominant, from 4 to 11 percent, partly counterbalanced the losses suffered by little bluestem. Basal cover was about 18 percent in 1939.

Basal cover in the overgrazed little bluestem type had been reduced to 11.5 percent in 1935 . Side-oats grama and blue grama constituted about half of the cover, which reached its minimum of 9.3 percent the next year. Although the bluestem all but disappeared, the total vegetation, including buffalo grass, improved steadily and attained a basal cover of 30 percent in 1939.

Studies in the Buchloe-Bouteloua type were begun in 1932 and extended in 1935 to include several grazing treatments. In 1937 quadrats were established in pastures in 10 different counties of western Kansas; some pastures had undergone various degrees of covering by dust.

Ungrazed pastures, formerly moderately grazed, with an approximately equal mixture of buffalo grass (Buchloe dactyloides) and blue grama grass in almost pure stands presented a basal cover of 80 to 90 percent. This decreased slowly until 1936 when it was only 58 percent, and the next year to 25 percent. Although fluctuating somewhat, this stand was further reduced to 22 percent in 1939 .

Deterioration was much greater in a similar, adjacent pasture that had been ungrazed for many years. Excessive growth of the vegetation during the good years preceding drought made it more susceptible to drought injury than pastures which had been moderately grazed. Basal cover was only 25 percent in 1935, and 11 the next year. Thereafter there was a slow but steady improvement until 1938-39 when it was again 26 percent. There was little change in composition of the vegetation, although previous to 1935 buffalo grass had suffered the greater loss. In portions of the pasture there were large areas almost without vegetation. Areas suffering the greatest losses had been composed more largely of buffalo 
grass than blue grama. Where local dust deposits exceeded $1 / 2$ inch in depth the short grasses were handicapped and a cover an inch or more in depth was usually fatal.

Despite quantities of seedlings, and rapid propagation of buffalo grass by stolons in 1935 and at other times, periods favorable for growth were usually too short to result in establishment. Flower stalks were sometimes formed, but few seeds matured. With dusting and denudation, rainfall became less efficient and runoff greatly increased.

In the short grass type moderately grazed during the drought, an average basal cover of about 50 percent was found in 1935 . This was reduced to about 5 percent in 1936 , less than $1 / 2$ percent being buffalo grass. It then gradually increased to 28 percent by 1939. In some areas buffalo grass, which often remained only in shallow depressions, increased more rapidly, in others, the more drought-resistant codominant, blue grama grass. Few other species were even of minor importance.

Overgrazed short grass ranges were reduced to a cover of 22 percent or less than half of that under moderate grazing. Blue grama grass was reduced to 2 percent, buffalo grass to less than 1 percent, and the total basal cover to about 2.5 percent when most depleted in 1936. Areas 10 to 15 feet in diameter and entirely bare of grass were frequent. Recovery was aided by reduced grazing pressure and basal cover increased year by year to 7,13 , and 19 percent.

Basal cover in ungrazed, moderately grazed, and overgrazed short grass ranges (where the cover in 1932 varied from 88 to 80 percent, respectively), was reduced in a somewhat parallel manner. Maximum reduction was least and a year later in ungrazed grassland. Percentages of cover were, in order, 65, 48 , and 22 in 1935 but 58, 7, and 3 in 1936. By 1938 the cover was 31,22 , and 13 percent, respectively. Further heavy losses on overgrazed ranges were recorded in 1940

The transition area between the little bluestem and short grass exhibited several mixtures. Even where large amounts (40 percent) of little bluestem were found, total loss of the species usually occurred. Total basal cover was reduced from 65 to 25 percent. Owing to the entrance of side-oats grama and to a great increase of short grasses, about 50 percent cover was present in 1939.

Drought over most of the range area, except where it was accompanied by dust burial, resulted in severe thinning of the short grasses rather than their complete destruction.

Side-oats grama was intermixed with short grasses in more xeric situations in the ecotone before the drought. Where it constituted 60 percent of the cover in 1932, it decreased to 3 percent by 1936 and scarcely gained thereafter. The short grasses, about equally intermixed, were more resistant to desiccation. 'They decreased from 22 to 11 percent, but by 1939 doubled their original basal area. Thus, the total basal cover of 82 percent (1932) was reduced to 14 in 1936 but was 50 percent in 1939 .

Where several mid grasses, including wire grasses (Aristida purpurea and A. longiseta), were intermixed with short grasses in the transitional area, all disappeared in 1 to 3 years. The short grasses were at a low ebb in 1936 but subsequently regained the ground lost by the mid grasses, so that the initial basal cover of 34 percent was again attained.

Great changes also occurred in the big bluestem type, although decrease in available soil moisture was slower here as was also decrease in abundance of vegetation. Western wheat grass (Agropyron smithii), side-oats grama and other more xeric grasses partially replaced big bluestem, tall panic grass (Panicum virgatum), and other mesic species. A loss of one fourth of the vegetation resulted from drought and consequent soil erosion and deposit.

Intensive studies of ranges were made in ten additional counties in western Kansas, beginning in 1937. All were in the short grass type. On lightly dusted and moderately grazed ranges basal cover varied from 10 to 33 percent. Percentage of buffalo grass usually averaged higher than that of blue grama. Variations in cover were usually closely correlated with the amount of rainfall. No permanent gains occurred by 1939 .

Under light dusting and overgrazing a cover of 5.5 percent increased to 18 in 1938 and to 26 in 1939 . At some stations this resulted from an excellent growth of buffalo grass. Where heavy dusting and moderate grazing occurred and buffalo grass and blue grama were about equally represented, the basal cover of 6 percent increased to 15 .

Vegetation suffered the greatest losses under heavy dusting and overgrazing. An average basal cover of 1 to 2 percent showed no increase by 1939 . This much-depleted type of grassland is of very wide distribution and constitutes a large portion of the vegetation near the center of the dust bowl.

Drought, overgrazing, and hordes of grasshoppers have caused great reduction in carrying capacity of the range. Yield of palatable forage in overgrazed pastures is less than 10 percent of that produced in well-managed ones. Where 10 to 12 acres was formerly required to sustain one animal unit, 30 to 50 acres are now needed.

Several years with normal or above normal precipitation and with the most judicious range management will be required to restore the former cover of grasses.

\section{LITERATURE CITED}

Albertson, F. W. 1937. Ecology of mixed prairie in west central Kansas. Ecol. Monog. 7 : 481-547.

- 1938. Prairie studies in west central Kansas. Kans. Acad. Sci. Trans. 41 : 77-83.

1939. Prairie studies in west central Kansas. Kans. Acad. Sci. Trans. 42: 97-107.

Bennett, H. H. 1939. Soil conservation. 993 pp. MeGraw-Hill Book Co. 
Brandon, J. F., and A. Kezer. 1936. Soil blowing and its control in Colorado. Colo. Agr. Expt. Sta. Bul. 419.

Clements, F. E. 1929. Climatic cycles and changes of vegetation. Rep. Confer. Cycles Carnegie Inst. Wash. 3-4: $64-71$.

1936. Nature and structure of the climax. Jour Ecol. 24: 253-284.

, and R. W. Chaney. 1937. Environment and life in the Great Plains. Carnegie Inst. Wash., Suppl. Pub. 24. $52 \mathrm{pp}$.

Flora, S. D. Climatological data. U. S. Dept. Agr. Weather Bur. Topeka, Kans.

Great Plains Committee. 1936. The Future of the Great Plains. U. S. Govt. Printing Office. Wash., D. C. $194 \mathrm{pp}$.

Joel, A. H. 1937. Soil conservation reconnaissance survey of the southern Great Plains wind-erosion area U. S. Dept. Agr. Tech. Bul. 556. 68 pp.

Lugn, A. L. 1939. Nebraska in relation to the problems of Pleistocene stratigraphy. Amer. Jour. Sci. 237: 877.

McArdle, R. E., and D. F. Costello. 1936. The virgin range and the white man's toll. U. S. Dept. Agr. Sen. Doc. 199, Sep. No. 2. Pp. 71-116.

McDonald, A. 1938. Erosion and its control in Oklahoma Territory. U. S. Dept. Agr. Misc. Pub. 301. 47 pp.

Riegel, D. A. 1940. A study of the variations in the growth of blue grama grass from seed produced in various sections of the Great Plains region. Kans. Acad. Sci. Trans., 43: 155-171.
Savage, D. A. 1937. Drought survival of native grass species in the central and southern Great Plains, 1935. U. S. Dept. Agr. Tech. Bul. 549. 55 pp.

1939. Grass culture and range improvement in the central and southern Great Plains. U. S. Dept. Agr. Cir. 491. 56 pp.

and L. A. Jacobson. 1935. The killing effect of heat and drought on buffalo grass and blue grama grass at Hays, Kansas. Amer. Soc. Agron. Jour. 27: 566-582.

Shantz, H. L. 1911. Natural vegetation as an indicator of the capabilities of land for crop production in the Great Plains area. U. S. Dept. Agr. Bul. 201. 100 pp. 1923. The natural vegetation of the Great Plains region. Assoc. Amer. Geog. Ann. 13: 81-107.

Weaver, J. E. 1924. Plant production as a measure of environment. Jour. Ecol. 12: 205-237.

Weaver, J. E., and F. W. Albertson. 1936. Effects of the great drought on the prairies of Iowa, Nebraska, and Kansas. Ecology 17: 567-639.

- 1939. Major changes in grassland as a result of continued drought. Bot. Gaz. 100: 576-591.

1940. Deterioration of grassland from stability to denudation with decrease in soil moisture. Bot. Gaz. 101 : 598-624.

- 1940a. Deterioration of midwestern ranges. Ecology 21 : 216-236.

Wooster, L. D. 1935. Notes on the effects of drought on animal population in western Kansas. Kans. Acad. Sci. Trans. 38 : 351-352.

1939. The effect of drought on rodent population. Turtox News. Vol. 17, No. 1 